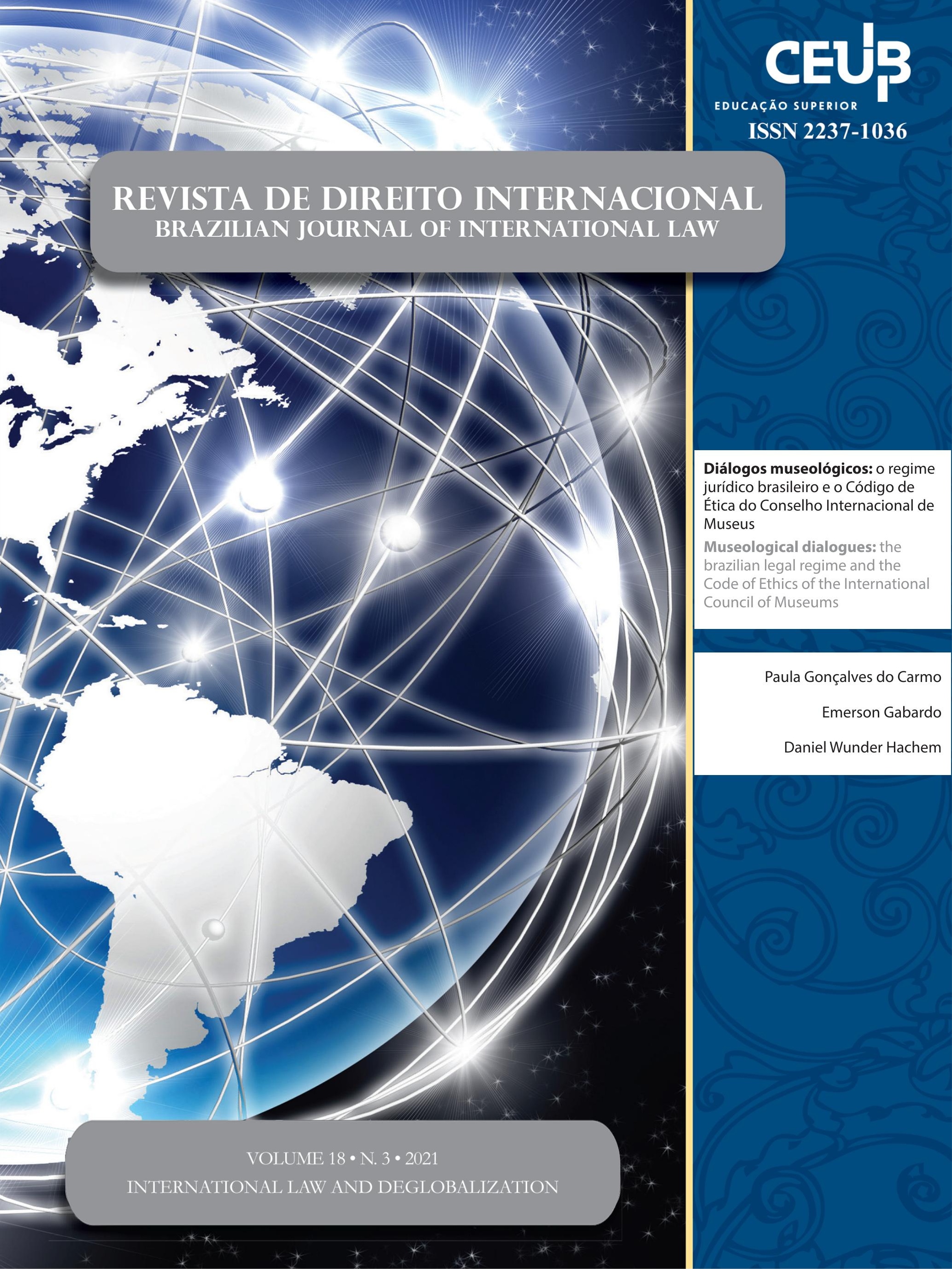




\section{Sumário}

Dossiê

EDITORIAL: INTERNATIONAL LAW AND DE-GLOBALIZATION 16 Ivette Esis, Jaime Tijmes e Juan Enrique Serrano

El régimen jurídico de la Inversión Extranjera Directa: ¿De la limitación a la desGLOBALIZACIÓN?

Ivette Esis Villarroel e Yoselyn Bermúdez Abreu

Desglobalização, Brexit e os novos acordos entre Reino Unido e União Europeia .34 Angela Limongi Alvarenga Alves e Daniel Freire e Almeida

FisCALIDAD Y DESGLOBALIZACIÓN EN UN MUNDO CRECIENTEMENTE UNILATERAL Julio César Muñiz Pérez

Covid, Covax e o Refluxo da Governança Global Salem Hikmat Nasser e Luiza Nogueira Papy

The International Monetary Fund and COVID-19: Old and New Challenges of a Post-World War II INTERNATIONAL INSTITUTION

Virdzhiniya Petrova Georgieva

Artigos Sobre outros temas

RULE OF LAW IN THE INTERNATIONAL ARENA: THE IMPORTANCE OF PRACTICES OF LEGALITY . 112 Angela Jank Calixto

THE WITHDRAWAL OF MEMBER-STATES FROM HUMAN RIGHTS COURTS: IS THE JUDICIALIZATION OF MEGA-POLITICS A NECESSARY CONDITION?. 132

Mikelli Marzzini Lucas Alves Ribeiro e Ernani Rodrigues de Carvalho Neto 
Princípio da precaução e mudança climática: uma análise do Acordo de Paris e das Conferências das Partes.

Jamille Bergamaschine Mata Diz e Carolina Mendonça de Siqueira

A INTERAÇÃo ENTRE OS ESPAÇOS CONSTITUCIONAIS NACIONAIS E INTERNACIONAIS E SEUS IMPACTOS NO SISTEMA DE FONTES DO DIREITO: AS LIÇÕES DA PROTEÇÃO COOPERATIVA DE DIREITOS HUMANOS E O CASO DA INTEGRAÇÃO EUROPEIA ...................................................... 173

Diego Fernandes Guimarães

WTO’s Engagement with National Law: Three Illustrations from India 193 Ravindra Pratap

GESTÃo MIGRATÓRIA E INTEGRAÇÃo REGIONAL: UMA ANÁLISE SOBRE A REGULAMENTAÇÃo NORmativa dos fluxos migratórios irregulares na União Europeia À luz do Novo Pacto Europeu sobre Migração e Asilo.................................................................. 212 João Mauricio Malta Cavalcante Filho e Eugênia Cristina Nilsen Ribeiro Barza

The African Regional Human and Peoples' Rights System: 40 years of progress and CHALLENGES. 232 Juan Bautista Cartes Rodríguez

The USMCA Sunset Clause 258 Jaime Tijmes-Ihl e Yvonne Georgina Tovar Silva

REFLEXÕES SOBRE A UNIVERSALIDADE DO DIREITO INTERNACIONAL DOS DIREITOS HUMANOS A RESPEITO DA PROTEÇÃO ÀS MULHERES 273 Érica Rios de Carvalho

A CRItical legal anAlysis OF GENDER EQUALITY IN INTERNATIONAL TRADE AgREEMENTS...287 Parul Shukla e Sheikh Sultan Aadil Huque

FEMinicídio, FEMicídio E Ódio NA AGENDA: o ASSASSinAto DAS MUlHERES NA AmÉriCA LATINA...... 309 Vinícius Ferreira Baptista

LEGAL IDEOLOGY IN THE CONTEXT OF DEVELOPMENT OF THE LEGAL STATE AND FORMATION OF THE CIVIL SOCIETY IN UKRAINE 
Direito INTERNACIONAL PÚBLICO NO ENTREgUERRAS (1919-39): A INSTITUCIONALIZAÇÃO DOS PROJETOS JURÍDICOS DE PAZ E MANEJO DOS POVOS NÃO SOBERANOS.

Hugo Luís Pena Ferreira

O Caso Gomes Lund (“Guerrilha Do Araguaia”) dez anos depois: Desafios para o cumPRIMENTO INTEGRAL PELO ESTADO BRASILEIRO

João Gabriel Archegas, Felipe Klein Gussoli e Vivian Cristina Lima López Valle

DiÁlogos museológicos: o Regime jurídico brasileiro e o Código de Ética do ConseLHo InTERnacional de Museus.

Paula Gonçalves do Carmo, Emerson Gabardo e Daniel Wunder Hachem 


\title{
Diálogos museológicos: o regime jurídico brasileiro e o Código de Ética do Conselho Internacional de Museus*
}

\author{
Museological dialogues: the brazilian \\ legal regime and the Code of Ethics of the \\ International Council of Museums
}

\author{
Paula Gonçalves do Carmo** \\ Emerson Gabardo*** \\ Daniel Wunder Hachem ${ }^{* * * *}$
}

* Recebido em 13/08/2021

Aprovado em 30/08/2021

** Especialista em Direito Administrativo pelo Instituto de Direito Romeu Felipe Bacellar (Curitiba-PR); Bacharel em Direito pela Universidade Federal do Paraná; Advogada.

E-mail: gcarmopaula@gmail.com

*** Professor Titular de Direito Administrativo da Pontifícia Universidade Católica do Paraná e Professor Associado do Departamento de Direito Público da Universidade Federal do Paraná. Doutor em Direito do Estado pela Universidade Federal do Paraná. Pós-doutorado na Fordham University School of Law (EUA - 2013). Professor Visitante Sênior no J. W. Peltason Center for the Study of Democracy at University of California (EUA - 2020). Exvice-presidente do Instituto Brasileiro de Direito Administrativo (2017-2019). Editor Chefe da International Journal of Digital Law. E-mail: emerson.gabardo.br@gmail.com

**** Professor da Graduação, Mestrado e Doutorado em Direito da Pontifícia Universidade Católica do Paraná e da Universidade Federal do Paraná (Curitiba-PR); Doutor e Mestre em Direito do Estado pela UFPR; Pós-Doutorado pela Université Paris 1 Panthéon-Sorbonne (2017); Professor Visitante da École de Droit de la Sorbonne (2018/2020); Advogado. E-mail: danielhachem@gmail.com

\section{Resumo}

Neste artigo analisam-se o sistema jurídico que rege as práticas de museus no Brasil, bem como as normas internacionais aplicáveis ao setor, em especial a regulamentação criada pelo Conselho Internacional de Museus (ICOM) e seu Código de Ética. Além disso, problematiza-se a influência do sistema internacional de proteção de patrimônio cultural no Direito nacional e contextualizam-se, historicamente, a disciplina legal dos direitos culturais no Brasil e o arranjo institucional e legal que levou à atual democratização e à autonomia do setor de museus no país. Posteriormente, explica-se a relevância do ICOM no tema relativo à museológica global, bem como seu Código de Ética assume caráter normativo de soft law. Por fim, é feita uma comparação das normas gerais do Brasil para museus com elementos-chave do Código de Ética do ICOM, para compreender se a lei brasileira alinhase à prática internacional e em qual medida. Utiliza-se uma metodologia analítico-descritiva, com a técnica de investigação bibliográfica doutrinária e documental. Conclui-se que as relações entre Direito internacional e Direito administrativo interno são benéficas para os museus brasileiros, no campo do dever ser, mas há o risco de não haver esforço político-institucional nacional para o aperfeiçoamento do setor.

Palavras-chave: Proteção do patrimônio cultural; Regime jurídico dos museus; Conselho Internacional de Museus; Código de ética; Soft law.

\section{Abstract}

The article aims to analyze the legal system that governs the practices of museums in Brazil, as well as the international standards applicable to the sector, especially the regulations created by the International Council of Museums (ICOM) and its Code of Ethics. It questions the influence of the international cultural heritage protection system in national law. The research contextualizes the legal discipline of cultural rights in Brazil and the institutional and legal arrangement that led to the current democratization 
and autonomy of the museum sector in the country. Afterwards, it explains the relevance of ICOM in the global museological field and how its Code of Ethics assumes the normative character of soft law. Finally, a comparison of Brazil's general standards for museums is made with key elements of the ICOM Code of Ethics, to understand whether Brazilian law is in tune with international practice and to what extent. It uses an analytical-descriptive methodology, with the scholarly and documental bibliographic investigation technique. It concludes that the relations between international law and national administrative law are very beneficial for Brazilian museums in a deontological perspective, but that this system may be at risk if there is no continuous national political-institutional effort concerned with the improvement of the sector.

Keywords: Protection of cultural heritage; Legal regime for museums; International Council of Museums; Code of ethics; Soft law.

\section{Introdução'}

Políticas de fruição cultural e proteção de patrimônio são necessárias em um contexto de formação de identidades coletivas e reconhecimento do indivíduo como parte de um todo. Entretanto, isto não diz respeito somente ao passado, mas também ao futuro de uma sociedade. A preservação e exposição de bens de valor histórico, artístico e cultural, de importância em nível nacional ou universal, bem como as manifestações que registram a trajetória das pessoas pela história, inserem-se em um contexto de importância que exige políticas culturais e ações institucionalizadas.

Os museus são muitas vezes considerados como tema de "segundo plano" na elaboração de políticas públicas, pois não seriam "úteis" a uma lógica tecnicista de vida. Na verdade, eles são centrais para o desenvolvimento do ser humano, para sua conexão com a sociedade e autoconhecimento - enfim, para a formação de uma cultura ou vivência com intercâmbio de narrativas.

Nesse sentido, para compreender, com maior clareza, o momento atual da proteção institucional de bens

\footnotetext{
${ }^{1} \mathrm{O}$ presente trabalho foi realizado com apoio da Coordenação de Aperfeiçoamento de Pessoal de Nível Superior - Brasil (CAPES) Código de Financiamento 001 (Programa CAPES/PRINT).
}

culturais no Brasil e, posteriormente, os desdobramentos da matéria em âmbito global e na seara do Direito Internacional, faz-se importante traçar uma linha histórica a partir de sua origem no país. Isto porque, para se avaliar se há aperfeiçoamentos ou retrocessos no setor, e analisá-los criticamente, é imperioso perceber que os conceitos, consensos e direitos impactados não são estanques e imutáveis, mas demandam contínua vigilância, discussão e atualização no tocante às formas de sua proteção e concretização.

No campo legal brasileiro, a cultura nacional passou a ser um assunto de interesse estatal e proteção institucional na década de 30, no Estado Novo, período ditatorial do governo de Getúlio Vargas, mais especificamente no ano de 1937. ${ }^{2}$ Para conservar o "patrimônio histórico e artístico nacional", foi promulgado o Decreto-Lei n. ${ }^{\circ}$ 25, de 30 de novembro de 1937. Esse marco legal criou o instituto jurídico "tombamento" e os quatro "Livros do Tombo", que consistiu na principal política pública brasileira de conservação do patrimônio histórico, cultural, artístico e arqueológico, móvel e imóvel, até meados dos anos 2000.

O tombamento existe até os dias de hoje e pode ser conceituado como "procedimento administrativo que objetiva inscrever determinado bem, revestido de requisitos necessários para integrar o patrimônio cultural brasileiro, em livro próprio, para efeitos de preservação". ${ }^{3}$ Contudo, os valores que regiam sua aplicação são muito diversos dos utilizados atualmente, em razão das mudanças profundas no Direito e sociedade brasileira.

O início da institucionalização da cultura e do patrimônio cultural nacional se deu em virtude de um projeto de poder que visava, para fins de propaganda sistemática, idealizar uma cultura que unificasse a ordem política e social. ${ }^{4}$ O Serviço do Patrimônio Histórico e Artístico Nacional (SPHAN) foi criado meses antes da

\footnotetext{
2 BRASIL. Decreto-Lei ñ 25 , de 30 de novembro de 1937. Organização e proteção do Patrimônio Histórico e Artístico Nacional. Disponível em: http://www.planalto.gov.br/ccivil_03/decreto-lei/del0025.htm Acesso em: 23 jul. 2019.

3 NOHARA, Irene Patrícia. Direito administrativo. 9. ed. São Paulo: Atlas, 2019. p. 828.

${ }^{4}$ SILVA, Carlos Henrique Gomes da; PINHEIRO, Lena Vania Ribeiro. Políticas públicas para museus no Brasil: do IPHAN ao IBRAM. In: ENCONTRO NACIONAL DE PESQUISA EM CIÊNCIA DA INFORMAÇÃO, 14., 2013, Florianópolis. Anais [...]. Florianópolis: UFSC, 2013. Disponível em: http://repositorio.ibict. br/handle/123456789/459 Acesso em: 12 mar. 2019.
} 
edição do Decreto-Lei n. ${ }^{0} 25,{ }^{5}$ mas, como esse decreto teve a sua consolidação como o principal órgão responsável pela proteção da memória nacional e, assim, permaneceu até 1979, com a mudança de nome para IPHAN - Instituto Nacional do Patrimônio Histórico e Artístico Nacional — que existe até hoje —, mas sem a centralidade de outrora, em razão da criação de novos órgãos na estrutura do governo federal, como o Instituto Brasileiro de Museus - IBRAM, em 2009.

O assunto do patrimônio (cultural heritage) e cultura (cultural property) assumiu relevância para o Estado e o Direito - mas o sentido de "memória nacional" de hoje é diferente da concepção daquela época, como se verá adiante, repercutindo a natureza e acervos de museus, por consequência. A intenção do então governante do país era a construção de uma identidade única nacional, pois ele entendia a cultura como "campo privilegiado à formação da nacionalidade brasileira e difusão ideológica do Regime". ${ }^{6}$ As teses de construção da identidade nacional foram historicamente desastrosas, principalmente quando operavam em favor de um projeto autoritário de poder e invisibilidade de grupos vulneráveis. ${ }^{7}$ Por esse motivo, é importante o estudo desse tema, a fim de ser evitado o retorno de perspectivas culturais não plurais, notadamente em relação à formulação e à implementação de políticas públicas relativas a direitos sociais. ${ }^{8}$

A imagem que se pretendia passar era de um governo que se preocupava com a cultura do seu povo e, para tanto, a daria como "pronta". O projeto pretendia (e foi plenamente eficaz até meados dos anos 70) ter o

5 POZZER, Márcio Rogério Olivato. Os paradigmas da administração pública e as políticas de patrimônio cultural em museus de Brasil e México. São Paulo, 2015. Tese (Doutorado em Comunicação) - Escola de Comunicação e Artes, Universidade de São Paulo, São Paulo, 2015. p. 129. 6 SILVA, Carlos Henrique Gomes da; PINHEIRO, Lena Vania Ribeiro. Políticas públicas para museus no Brasil: do IPHAN ao IBRAM. In: ENCONTRO NACIONAL DE PESQUISA EM CIÊNCIA DA INFORMAÇÃO, 14., 2013, Florianópolis. Anais [...]. Florianópolis: UFSC, 2013. p. 2. Disponível em: http://repositorio. ibict.br/handle/123456789/459 Acesso em: 12 mar. 2019.

7 BREPOHL, Marion; GONÇALVES, Marcos; GABARDO, Emerson. As violências do estado de exceção e a defesa da memória contra a invisibilidade dos grupos vulneráveis. Revista Brasileira de Estudos Politicos, Belo Horizonte, n. 117, p. 321-361, jul./dez. 2018.

8 CARVAlHO, Osvaldo Ferreira de. As políticas públicas como concretização dos direitos sociais. Revista de Investigaçoes Constitucionais, Curitiba, v. 6, n. 3, p. 773-794, set./dez. 2019; HACHEM, Daniel Wunder. São os direitos sociais "direitos públicos subjetivos"? Mitos e confusões na teoria dos direitos fundamentais. Revista de Estudos Constitucionais, Hermenêtica e Teoria do Direito, v. 11, n. 3, p. 404-436, set./dez. 2019. monopólio no discurso do que seria ou não cultura e patrimônio cultural do país. Criou, assim, um discurso "técnico" que buscava transformar os bens selecionados em exemplos de "arte verdadeira". Sendo assim, nessa perspectiva, cabe aos monumentos cumprir a sua função simbólica de serem "emblemas da verdade", elevando o Estado e engrandecendo a nação. ${ }^{9}$ Visava-se à construção de símbolos, à criação e à exaltação de "heróis nacionais". Inclusive, diz-se que a criação do Museu Imperial, em 1940, teve como intuito o culto ao império e à nobreza, a valorização das tradições e a continuidade do passado. A intenção era homenagear D. Pedro II e não apenas retratar o período histórico em questão. ${ }^{10}$

O governo visava, na verdade, à homogeneização da população, dando um senso de unidade nacional, visando estimular um sentimento de "amor à pátria" nos cidadãos. ${ }^{11}$ Isto seria atingido, por meio do elitismo e do paternalismo, a propagação de uma cultura que passou a ser pretendida como "oficial": os intelectuais dentro da burocracia estatal seriam "porta-vozes das massas", intermediários entre o governo e o povo, porque as autoridades acreditavam que apenas eles tinham a capacidade de se organizar sozinhos; afinal, eram "homens de cultura". ${ }^{12}$ Eles diriam o que deve ser lembrado e o que deve ser esquecido.

$\mathrm{Na}$ Era Vargas, os museus federais, idealizados nas décadas de 30 e 40, se colocaram no papel de formação de acervos que criassem narrativas factuais e culto a personalidades importantes do passado. Não obstante, apesar da conservação de artefatos históricos nos museus, o foco era, na verdade, proteger o patrimônio edificado, os monumentos, e não a criação de um sistema

9 SILVA, Carlos Henrique Gomes da; PINHEIRO, Lena Vania Ribeiro. Políticas públicas para museus no Brasil: do IPHAN ao IBRAM. In: ENCONTRO NACIONAL DE PESQUISA EM CIÊNCIA DA INFORMAÇÃO, 14., 2013, Florianópolis. Anais [...]. Florianópolis: UFSC, 2013. p. 9. Disponível em: http:/ / repositorio. ibict.br/handle/123456789/459 Acesso em: 12 mar. 2019.

${ }^{10}$ SANTOS, Myrian Sepúlveda dos. Museu imperial: a construção do Império pela República. In: CHAGAS, Mário; ABREU, Regina (orgs.). Memória e patrimônio: ensaios contemporâneos. 2. ed. Rio de Janeiro: Lamparina, 2009. p. 122-123.

${ }^{11}$ SILVA, Carlos Henrique Gomes da; PINHEIRO, Lena Vania Ribeiro. Políticas públicas para museus no Brasil: do IPHAN ao IBRAM. In: ENCONTRO NACIONAL DE PESQUISA EM CIÊNCIA DA INFORMAÇÃO, 14., 2013, Florianópolis. Anais [...]. Florianópolis: UFSC, 2013. p. 11. Disponível em: http://repositorio.ibict.br/handle/123456789/459 Acesso em: 12 mar. 2019.

12 FONSECA, Maria Cecília Londres. Patrimônio em processo: trajetória da política federal de preservação no Brasil. Rio de Janeiro: UERJ, 1997. p. 13. 
de museus e investimentos na área. Nos anos do regime militar, ${ }^{13}$ sobretudo na década de 70 , os museus foram usados, também, para propagar o discurso oficial do governo e suas narrativas voltadas ao culto do Estado e ao sentimento de nação homogênea.

Para o entendimento da época, o requisito valorativo oficial era a "excepcionalidade", ou seja, para que um bem cultural (cultural good) integrasse o patrimônio cultural (cultural heritage) assim reconhecido pelo Estado, em âmbito nacional/federal, tinha de ter algo de excepcional - fora do normal ou popular. Essa "excepcionalidade" levava em conta o valor estético do bem, considerando-se um conceito de arte e arquitetura referencial quase que, de forma exclusiva, devoto do padrão eurocêntrico. ${ }^{14} \mathrm{~A}$ noção de patrimônio que vigorava na época em que foi expedido o Decreto-lei n. ${ }^{\circ}$ 25/37 é compatível com essa narrativa. É possível, também, destacar a assimetria de quantidades de bens nacionais tombados entre as diversas regiões do país, um reconhecimento histórico desigual em níveis de federação, diminuindo o reconhecimento da diversidade cultural do país. ${ }^{15}$

A política de cultura em nível federal, desde 1937 até meados da década de 80, se prestava, de alguma forma, a operar em favor dos ideais do governante em questão - e, no século XX, o Brasil passou muitos anos de regimes autoritários. ${ }^{16}$ Havia uma relação mecânica entre exposição e público. Na realidade, o cenário brasileiro não destoava muito do cenário mundial, no qual havia vários Estados com regime autoritário. Myrian Sepúlveda dos Santos explica que o cenário global, em relação aos museus, naquela época, era o espaço da história oficial, do autoritarismo das elites ou, ainda, de "socie-

\footnotetext{
13 SILVA, Carlos Henrique Gomes da; PINHEIRO, Lena Vania Ribeiro. Políticas públicas para museus no Brasil: do IPHAN ao IBRAM. In: ENCONTRO NACIONAL DE PESQUISA EM CIÊNCIA DA INFORMAÇÃO, 14., 2013, Florianópolis. Anais [...]. Florianópolis: UFSC, 2013. p. 11-12. Disponível em: http://repositorio.ibict.br/handle/123456789/459 Acesso em: 12 mar. 2019.

14 OLIVEIRA, Thiago Pires. Raízes históricas da proteção jurídica do patrimônio cultural no Brasil. Fórum de Direito Urbano e Ambiental - FDUA, Belo Horizonte, ano 11, n. 62, mar./abr. 2012. p. 8.

15 POZZER, Marcio Rogerio Olivato. Políticas públicas para o patrimônio cultural na América Latina: a experiência brasileira e equatoriana e o papel do Banco Interamericano de Desenvolvimento. 2011. Dissertação (Mestrado em Integração da América Latina) - Integração da América Latina, Universidade de São Paulo, São Paulo, 2011. p. 67-68.

16 Estado Novo, período de governo autoritário de Getúlio Vargas, entre 1937 e 1946; Ditadura Cívico-Militar no Brasil vigente de $1^{\circ}$ de abril de 1964 à 15 de março de 1985.
}

dades sem cultura". Muitos acreditavam que, com o advento dos meios de comunicação de massa, os museus estariam fadados ao seu fim. ${ }^{17}$

Mas, se essa era a retórica dos discursos oficiais, segundo o discurso museológico de instituições internacionais a partir dos anos $1970,{ }^{18}$ como o International Council of Museums (ICOM) e UNESCO, o museu deveria ser uma

instituição a serviço da sociedade e do seu desenvol-
vimento, aberta ao público, que adquire, conserva,
pesquisa, comunica e expõe o património tangível
e imaterial da humanidade e do seu meio ambiente
para fins de educação, estudo e fruição. ${ }^{19}$

Com inspiração nessa perspectiva da UNESCO, e considerando-se o contexto de redemocratização do país posterior a $1985,{ }^{20}$ foi criado o Ministério da Cultura (MinC) na gestão do presidente José Sarney. Já em 1986, foi instituído o Sistema Nacional de Museus. ${ }^{21}$ Tratou-se da primeira tentativa no país de implementar

17 SANTOS, Myrian Sepúlveda dos. Museus brasileiros e política cultural. Revista Brasileira de Ciências Sociais, São Paulo, v. 19, n. 55, p. 53-72, jun. 2004. p. 53. Disponível em: http://www.scielo.br/scielo. php?script $=$ sci_arttext\&pid $=$ S010269092004000200004\&lng $=$ en $\&$ nrm=iso Acesso em: 25 jul. 2019.

18 International Council of Museums (ICOM), sobretudo a partir da histórica mudança orientativa de 1974, após a inclusão de "social orientation" no Estatuto do ICOM; e UNESCO, principalmente após a 1970 UNESCO Convention against illicit trafficking of cultural heritage. MURPHY, Bernice L. Charting the ethics landscape for museums in a changing world. In: MURPHY, Bernice L. (ed.). Museums, ethics and cultural heritage. Londres; Nova York: Routledge, 2016. p. 24-25.

19 Definição de "museu" do Estatuto do International Council of Museums (International Council of Museums - ICOM). Tradução livre. No original: "institution in the service of society and its development, open to the public, which acquires, conserves, research, communicates and exhibits the tangible and intangible heritage of humanity and its environment for the purposes of education, study and enjoyment". INTERNATIONAL COUNCIL OF MUSEUMS. Statutes as amended and adopted by the Extraordinary General Assembly on 9th June 2017 (Paris, France). Disponível em: https:/ /icom.museum/ wp-content/uploads/2018/07/2017_ICOM_Statutes_EN.pdf Acesso em: 5 jul. 2021.

${ }^{20}$ CUNHA, Fernando José Gonçalves; ARAFA, Mohamed A.; BENVINDO, Juliano Zaiden. The Brazilian Constitution of 1988 and its ancient ghosts: comparison, history, and the ever-present need to fight authoritarianism. Revista de Investigações Constitucionais, Curitiba, v. 5, n. 3, p. 17-41, set./dez. 2018.

21 POZZER, Marcio Rogerio Olivato. Políticas públicas para o patrimônio cultural na América Latina: a experiência brasileira e equatoriana e o papel do Banco Interamericano de Desenvolvimento. 2011. Dissertação (Mestrado em Integração da América Latina) - Integração da América Latina, Universidade de São Paulo, São Paulo, 2011. p. 130. 
uma política nacional para o setor, bem como fomentar a criação de sistemas museológicos estaduais.

A Constituição Federal promulgada em 1988 fez surgir um novo paradigma jurídico no Brasil, ${ }^{22}$ inaugurando uma ordem jurídico-social pautada em valores democráticos com base no reconhecimento da existência de um regime legal internacional. ${ }^{23}$ Desse modo, o setor cultural e as políticas culturais, incluindo as destinadas especificamente aos museus, passaram por reformulações gradativas e, como qualquer tema inserido no sistema jurídico, precisou ser interpretado segundo os novos vetores axiológicos da ordem legal então vigente.

Este é o objeto de estudo do presente artigo, que será analisado com base em uma metodologia descritivo-analítica, com o cotejamento entre o dever ser (regime jurídico) nos planos nacional e internacional. As fontes investigadas consistem em textos de leis, doutrina especializada (nacional e estrangeira), bem como documentos oficiais pertinentes. Particularmente, o problema a ser investigado consiste na seguinte questão: o quadro jurídico brasileiro está em consonância com o Código de Ética do ICOM e com as principais convenções internacionais do sistema de proteção de patrimônio cultural? Em caso afirmativo, o respeito a esse conjunto normativo de soft law é positivo ou negativo para o sistema de proteção? E, finalmente, há compatibilidade entre esse sistema ético internacional e o modelo de Estado Social da Constituição de 1988? Em outras palavras, é positiva a influência do Direito internacional no Direito constitucional e administrativo local? Por hipótese, acredita-se que todos os questionamentos possuem respostas afirmativas.

\footnotetext{
22 ALVARADO, Arturo. The Brazilian Constitution of 1988: a comparative appraisal. Revista de Investigaçoes Constitucionais, Curitiba, v. 5 , n. 3, p. $137-148$, set./dez. 2018 .

23 No artigo $4^{\circ}$ da Constituição está disposto rol dos princípios que regem as relações internacionais da República Federativa do Brasil e, entre eles, está "IX - cooperação entre os povos para o progresso da humanidade". Este princípio, em especial, tem aplicabilidade direta com a colaboração em um sistema universal de manutenção e aperfeiçoamento de museus. BRASIL. [Constituição (1988)]. Constituição da República Federativa do Brasil. Disponível em: http://www.planalto. gov.br/ccivil_03/constituicao/ConstituicaoCompilado.htm Acesso em: 5 jul. 2021.
}

\section{Os direitos culturais no Brasil e a formação de um setor museológico}

\subsection{Releitura do direito à cultura na Constituição brasileira de 1988}

A Constituição Brasileira de 1988 conferiu importante reconhecimento ao patrimônio cultural e expandiu, significativamente, os sentidos do que deve ser tutelado, não apenas pelo Estado, mas com a colaboração da comunidade, conforme dita o art. $216, \$ 1^{\circ}$, da Lei Maior do país. ${ }^{24}$ A partir do final dos anos 1970, as mudanças no sentido da expressão "patrimônio cultural" começaram a florescer nos órgãos federais de criação e implementação de políticas culturais, ${ }^{25}$ ao menos na esfera dos discursos e debates, e se estenderam nas duas décadas seguintes. Isto ocorreu, em parte, devidos às mudanças políticas da época em nível internacional tais como a inclusão da matéria em uma pauta globalizada, por meio da atuação de organizações como a UNESCO e o International Council of Museums. Ademais, o declínio do regime ditatorial militar no Brasil levou à definição de novos valores e interesses para o setor, expandindo o conceito de patrimônio cultural. Ocorreu, nesse período, uma "modernização na noção de patrimônio", vinculando a temática do patrimônio cultural ao desenvolvimento e, além disso, houve uma "politização da prática de conservação". ${ }^{26}$ Os agentes públicos passaram a usar o patrimônio cultural como forma de trazer cidadania a grupos marginalizados pelo Estado, tornando mais democrático o seu alcance.

Existe hoje uma concepção de patrimônio cultural que deve ser entendida como "plural", "diversa" e "dinâmica". ${ }^{27}$ Foi reconhecido pelo legislador brasileiro

\footnotetext{
${ }^{24}$ Art. 216. Constituem patrimônio cultural brasileiro os bens de natureza material e imaterial, tomados individualmente ou em conjunto, portadores de referência à identidade, à ação, à memória dos diferentes grupos formadores da sociedade brasileira, nos quais se incluem: $\int 1^{\circ}$ O Poder Público, com a colaboração da comunidade, promoverá e protegerá o patrimônio cultural brasileiro, por meio de inventários, registros, vigilância, tombamento e desapropriação, e de outras formas de acautelamento e preservação.

25 CNRC - Conselho Nacional de Referência Cultural e servidores do IPHAN vinculados à mentalidade do SPHAN

${ }^{26}$ FONSECA, Maria Cecília Londres. Patrimônio em processo: trajetória da política federal de preservação no Brasil. Rio de Janeiro: UERJ, 1997. p. 14

${ }^{27}$ Sobre o patrimônio cultural no Direito argentino: REYNA, Justo José. El procedimiento administrativo multidimensional como técnica regulatoria en materia ambiental, de patrimonio cultural y de
} 
que “o conceito de 'identidade' é algo variável, sobretudo quando se leva em conta as diversas heranças coloniais e vínculos cívicos". ${ }^{28}$ Esta perspectiva foi incorporada ao sistema jurídico por meio da Constituição de 1988, que passou a adotar como critério para incluir um bem ao "patrimônio cultural" tombado a "referência à identidade, à ação, à memória dos diferentes grupos formadores da sociedade brasileira", conforme redação do caput do art. 216. Houve mudança, inclusive, na nomenclatura, haja vista o abandono da expressão "patrimônio histórico e artístico". E, ainda, no caput deste artigo, foi incluída previsão relativa aos bens de natureza imaterial, ${ }^{29}$ em outro aspecto expandindo o conceito anterior do Decreto-Lei n. ${ }^{\circ}$ 25/1937. Dessa forma, agora, integra o patrimônio cultural brasileiro o que é interpretado como o previsto nesses incisos do art. 216 da Constituição, ou seja: I - as formas de expressão; II - os modos de criar, fazer e viver; III - as criações científicas, artísticas e tecnológicas; IV - as obras, objetos, documentos, edificações e demais espaços destinados às manifestações artístico-culturais; $\mathrm{e} \mathrm{V}$ - os conjuntos urbanos e sítios de valor histórico, paisagístico, artístico, arqueológico, paleontológico, ecológico e científico. O conceito de "patrimônio", portanto, abrange o meio ambiente, sendo a proteção ambiental natural também uma das facetas da proteção do patrimônio cultural..$^{30}$

Ao longo dos artigos 215, 216 e 216-A, há várias menções à valorização e à proteção de diversidade étnica e regional, ${ }^{31}$ das culturas populares, indígenas e afro-brasileiras, ${ }^{32}$ bem como as manifestações culturais de

pueblos originarios. A\&C - Revista de Direito Administrativo \& Constitucional, Belo Horizonte, ano 12, n. 50, p. 131-169, out./dez. 2012. ${ }^{28}$ GABARDO, Emerson; SALGADO, Eneida Desiree. El sistema de protección del patrimonio histórico urbano y minero en Brasil. Revista Catalana de Dret Ambiental, v. 9, n. 1, p. 1-26, 2018. p. 8.

29 A discussão sobre o enquadramento (ou não) da vaquejada como patrimônio cultural imaterial é uma questão relevante no tocante à matéria. LEAL, Mônia Clarissa Hennig; MORAES, Maria Valetina de. "Diálogo" entre poderes no Brasil?: da inconstitucionalidade da regulação da vaquejada à vaquejada como patrimônio cultural imaterial brasileiro: uma análise crítica. Revista de Investigações Constitucionais, Curitiba, v. 5, n. 1, p. 63-81, jan./abr. 2018.

${ }^{30}$ GOMES, Enéias Xavier. Direito fundamental à tutela do patrimônio cultural. Fórum de Direito Urbano e Ambiental - FDUA, Belo Horizonte, ano 14, n. 81, p. 16-21, maio/jun. 2015. p. 5.

31 BRASIL. [Constituição (1988)]. Constituição da República Federativa do Brasil. Disponível em: http://www.planalto.gov.br/ccivil_03/ constituicao/ConstituicaoCompilado.htm Acesso em: 5 jul. 2021.

32 BRASIL, Deilton Ribeiro; GOMES, Elaine Aparecida Barbosa. A diversidade cultural enquanto direito fundamental: o caso do povo indígena Wayãpi. Revista Direito Econômico e Socioambiental, v. 10, n. 3, p. 258-287, set./dez. 2019. outros grupos que participaram do "processo civilizatório nacional". ${ }^{33}$ Os mecanismos de proteção do patrimônio cultural brasileiro estão previstos no $₫ 1^{\circ}$ do artigo 216 da Constituição, mas não é rol taxativo, deixando de ser o tombamento o único instrumento jurídico de salvaguarda neste assunto. ${ }^{34}$

Existem meios judiciais de requerer a tutela do patrimônio cultural, como a ação popular (Lei n. ${ }^{\circ}$ 4.717/65) e, principalmente, a ação civil pública (Lei n. ${ }^{\circ}$ $7.347 / 85)^{35}$. Cabe ao Ministério Público, também, atuar nessa seara. Quanto aos mecanismos de repreensão jurídica na esfera penal, há previsão nos artigos 62, 63, 64 e 65 da Lei n. 9.605/98 (Lei de Crimes Ambientais). ${ }^{36}$

\subsection{Democratização das políticas públicas de cultura no Brasil}

Uma vez que significativa parte da doutrina reconhece a existência de um "direito fundamental ao patrimônio cultural", ${ }^{37}$ faz-se imprescindível a criação e implementação de políticas públicas sobre o tema. Nesse sentido, relevante o contexto que ensejou a inclusão do $\int 3^{\circ}$ do artigo 215 da Constituição, pela Emenda Constitucional n. ${ }^{\circ} 48$ de 10 de agosto de 2005, que instituiu a obrigação da elaboração, pelo Estado, de lei plurianual estabelecendo um Plano Nacional de Cultura (PNC). Essa emenda constitucional é resultado de trabalhos que se iniciaram em 2003 por iniciativa do governo federal e o - então existente - Ministério da Cultura, foram realizados debates públicos iniciados no Seminário Nacional Cultura Para Todos em 2003.38

\footnotetext{
33 ANDRADE JUNIOR, Nivaldo Vieira de. Ampliações do conceito de patrimônio edificado no Brasil. In: GOMES, Marco Aurélio A. de Filgueiras; Elyane Lins Corrêa (orgs.). Reconceituacõos contemporâneas do patrimônio. Salvador: EDUFBA, 2011. p. 151-152.

${ }_{34}$ CUNHA FILHO, Francisco Humberto; SALDANHA, Bianca de Souza. A desapropriação como instituto de proteção ao patrimônio cultural e análise da legislação aplicável. A C - Revista de Direito Administrativo \& Constitucional, Belo Horizonte, ano 18, n. 71, p. $197-$ 224, jan./mar. 2018.

35 NOHARA, Irene Patrícia. Direito administrativo. 9. ed. São Paulo: Atlas, 2019. p. 831.

36 FREITAS, Vladimir Passos de; FREITAS, Gilberto Passos de. Reflexões sobre a proteção penal do patrimônio histórico e cultural brasileiro. Revista de Direito Econômico e Socioambiental, Curitiba, v. 6, n. 1, p. 88-113, jan./jun. 2015. p. 95-97.

37 GABARDO, Emerson; SALGADO, Eneida Desiree. El sistema de protección del patrimonio histórico urbano y minero en Brasil. Revista Catalana de Dret Ambiental, v. 9, n. 1, p. 1-26, 2018. p. 3.

38 BRASIL. Ministério da Cultura. Diretrizes Gerais para o Plano Nacional de Cultura. 2. ed. Brasília: Ministério da Cultura, 2008. p. 14.
} 
Segundo o Caderno de Diretrizes para o Plano de Nacional de Cultura - , que explica o processo de debates e trabalhos ao longo de 9 anos para a promulgação da Lei n. ${ }^{\circ}$ 12.343/2010, que instituiu o Plano Nacional de Cultura e o Sistema Nacional de Informações e Indicadores Sociais, com duração de 10 anos (vigente até 2020), foram realizados 20 encontros do Seminário Cultura para Todos, em 2003, com a participação de diversos setores, o que permitiu a obtenção de subsídios para a Política Nacional de Cultura. ${ }^{39}$

O art. 216-A da Constituição Federal foi incluído ao texto legal por meio da Emenda Constitucional n. ${ }^{\circ}$ 71/2012. Pelo artigo 216-A, foi criado o Sistema Nacional de Cultura (2012), ${ }^{40}$ que se fundamenta nas diretrizes do Plano Nacional de Cultura, e estipula ações voltadas para o planejamento e gestão compartilhadas das políticas culturais entre todos os entes federados.

No processo de reestruturação dos órgãos da Administração Pública para proteção dos bens culturais e difusão dos direitos culturais, ocorreu um resgate da causa museológica no país. Naqueles debates, no âmbito do Plano Nacional de Cultura, foi incluída uma discussão sobre o papel que os museus teriam em concretizar direitos culturais.

A redemocratização do país e uma postura típica de Estado Social para a consecução de políticas públicas, ${ }^{41}$ inclusive relativa ao setor da cultura e de patrimônio, iniciou um processo de reestruturação. Em 2003, foi instituída a Política Nacional de Museus (PNM). Com ela o setor museológico ainda não detinha autonomia, ainda estava vinculado ao IPHAN (Instituto Nacional do Patrimônio Histórico e Artístico Nacional), mas foi criado o DEMU - Departamento de Museus e Centros Culturais, ${ }^{42}$ dentro da estrutura do IPHAN, que estaria

\footnotetext{
39 BRASIL. Lei no 12.343, de 2 de dezembro de 2010. Institui o Plano Nacional de Cultura - PNC, cria o Sistema Nacional de Informações e Indicadores Culturais e dá outras providências. p. 20. Disponível em: http://www.planalto.gov.br/ccivil_03/_ato2007-2010/2010/ lei/112343.htm Acesso em: 23 jul. 2019.

40 BRASIL. Ministério da Cidadania. Secretaria Especial da Cultura. Sistema Nacional de Cultura. Disponível em: http://cultura.gov.br/ sistema-nacional-de-cultura/ Acesso em: 23 jul. 2019.

${ }^{41}$ GABARDO, Emerson; SALGADO, Eneida Desiree. El sistema de protección del patrimonio histórico urbano y minero en Brasil. Revista Catalana de Dret Ambiental, v. 9, n. 1, p. 1-26, 2018. p. 21.

${ }^{42}$ BESSA, Simone Figueiredo. Musealização e ordenamento jurídico do Museu no Brasil: missão e função (conceito e prática) no Museu Nacional - UFRJ (séculos XIX-XX). 2017. Dissertação (Mestrado em Museologia e Patrimônio) - Universidade Federal do Estado do Rio de Janeiro, Rio de Janeiro, 2017. p. 64-65.
}

responsável por colocar em prática a Política Nacional de Museus.

A importância da Política Nacional de Museus estava na criação pioneira de uma política pública que era de fato nacional e não se voltava apenas aos museus da União, mas também aos estaduais e municipais. Ainda, foram incluídos os museus privados e de qualquer natureza jurídica, pois a Política Nacional de Museus visava ao início de uma articulação entre todos os entes federativos e a sociedade civil. Essa política tinha como um dos objetivos a criação do Sistema Brasileiro de Museus, ${ }^{43}$ o que foi concretizado com o Decreto n. ${ }^{\circ}$ 5.264, de 5 de novembro de 2004. Para coordenação do Sistema, foi instituído um Comitê Gestor com representação obrigatória de diversos ministérios do Poder Executivo federal, bem como de entidades da sociedade civil de qualquer natureza. Ou seja, passou a não se limitar a uma política formulada, apenas, por administradores públicos, embora estivesse o Sistema Brasileiro de Museus vinculado ao hoje extinto Ministério da Cultura.

O Sistema é um modelo de gestão em rede, que é forma de planejamento consolidado em experiências no setor museal de países como Portugal e Espanha. ${ }^{44}$ O objetivo desse tipo de gestão é dar autonomia aos participantes, mas, ao mesmo tempo, manter uma interdependência entre eles. Permite-se compartilhar realidades e aprender uns com a experiência dos outros, uma vez que os museus podem ter realidades diferentes e recursos diferentes para gerir. ${ }^{45} \mathrm{O}$ Sistema Brasileiro de Museus facilitaria a aquisição de acervo e disponibilização de recursos humanos, cooperação em pesquisas, proporia medidas para o desenvolvimento das instituições, por exemplo. A adesão dos museus é voluntária e, para tanto, precisariam assumir compromissos com a Instituição central, que era o Sistema Brasileiro de $\mathrm{Mu}-$ seus (na época).

\footnotetext{
43 BRASIL. Decreto $n^{\circ} 5.264$, de 5 de novembro de 2004. Institui o Sistema Brasileiro de Museus e dá outras providências. Disponível em: http://www.planalto.gov.br/ccivil_03/_ato2004-2006/2004/decreto/d5264.htm Acesso em: 23 jul. 2019.

${ }^{44}$ TOLENTINO, Átila Bezerra. Políticas públicas para museus: o suporte legal no ordenamento jurídico brasileiro. Revista CPC, São Paulo, n. 4, p. 72-86, maio/out. 2007. p. 80.

45 POZZER, Marcio Rogerio Olivato. Políticas públicas para o patrimônio cultural na América Latina: a experiência brasileira e equatoriana e o papel do Banco Interamericano de Desenvolvimento. 2011. Dissertação (Mestrado em Integração da América Latina) - Integração da América Latina, Universidade de São Paulo, São Paulo, 2011. p. 139-140.
} 
O avanço em uma gestão que não parte de, apenas, um polo de poder - embora a necessidade de uma coordenação para orientação - é uma forma de reorganização que ajuda a promover a cultura local e regional, além de inserir novos tipos de bens culturais nos acervos, pois novos tipos de museus obterão apoio e mais visibilidade ao integrar a rede. Para Márcio Pozzer, o principal avanço que o Sistema Brasileiro de Museus (instituído em novembro de 2004) obteve, em termos práticos, foi ser capaz de começar a fazer um diagnóstico sobre a situação dos museus no Brasil. ${ }^{46}$ Segundo Myrian Sepúlveda Santos, até meados de 2002 (data de sua pesquisa), não se sabia, de fato, o número de museus no país, qual o acervo predominante, a natureza jurídica das instituições existentes e, dos já identificados, não se conhecia quem seria o público frequentador (ou seja, não havia dados sobre o assunto). ${ }^{47}$

\subsection{Autonomia temática e institucional do setor museológico}

O aumento da complexidade do arranjo institucional do setor museológico e os esforços em torná-lo autônomo da seara do patrimônio cultural como national treasures, monumentos e sítios se justificam quando se compreendem as possibilidades, peculiaridades e a importância do museu. Este é o ambiente onde o bem cultural, quando, na forma material e móvel, se faz acessível ao público e onde é celebrado. ${ }^{48} \mathrm{Da}$ mesma forma, as exposições devem ser vistas como um espaço de interação, onde as pessoas se reconhecem e são identificadas, para levar ao protagonismo social. ${ }^{49}$ Por

\footnotetext{
46 POZZER, Marcio Rogerio Olivato. Políticas públicas para o patrimônio cultural na América Latina: a experiência brasileira e equatoriana e o papel do Banco Interamericano de Desenvolvimento. 2011. Dissertação (Mestrado em Integração da América Latina) - Integração da América Latina, Universidade de São Paulo, São Paulo, 2011. p. 140.

47 SANTOS, Myrian Sepúlveda dos. Museus brasileiros e política cultural. Revista Brasileira de Ciências Sociais. São Paulo, v. 19, n. 55, p. 53-72, jun. 2004, SANTOS, Myrian Sepúlveda dos. Museus brasileiros e política cultural. Revista Brasileira de Ciências Sociais, São Paulo, v. 19 , n. 55, p. 53-72, jun. 2004. p. 63. Disponível em: http://www. scielo.br/scielo.php?script $=$ sci_arttext\&pid $=$ S01026909200400020 0004\&lng=en\&nrm=iso Acesso em: 25 jul. 2019.

${ }^{48}$ CANCLINI, Néstor García. Culturas híbridas: estratégias para entrar e sair da modernidade. 2. ed. São Paulo: Edusp, 1998. p. 169.

49 MELO, Douglas Brandão de; CARVALHO, Rita de Cássia Moura. Relações entre patrimônio cultural e museus: um referencial teórico para o desenvolvimento. Mosaico, v. 7, n. 10, 2016. Disponível em: http://bibliotecadigital.fgv.br/ojs/index.php/mosaico/article/ view/64725 Acesso em: 12 mar. 2019. p. 11.
}

isso o museu, na sua dimensão de espaço de celebração de memórias, não deve ser neutro e apolítico, porque a memória coletiva é temporal, logo, ao ser neutro, essa memória coletiva se perderá em razão da fluidez do momento vivido. ${ }^{50}$

Na construção de um patrimônio cultural, por existirem escolhas e juízos de valor que incidem na eleição de quais valores proteger e narrativa contar, as exposições não deixam de ser arbitrárias em alguma medida. Isto porque, ao se escolher pela ação preservacionista, há a seleção e a legitimação de alguma cultura. ${ }^{51}$ De fato, é geralmente uma cultura dominante. Por isso, entrar em um museu não significa um mero ingresso em um edifício; trata-se de uma "ação social". ${ }^{52}$

A prática atual reconhece que o museu existe nas mais diversas formas e, assim, deve ser por conta da variedade de possibilidades de exposição de modos, fazeres e bens de cultura. É a "museodiversidade", ${ }^{53}$ que na contemporaneidade diz respeito às diferenças do tipo de acervo,${ }^{54}$ temas, abordagens, tamanhos de estrutura física, modos de gestão. Atualmente, também são considerados instituições museais os jardins botânicos e zoológicos, aquários, galerias de arte, centros científicos, planetários, reservas naturais, centros culturais, bem como lugares que preservam valores imateriais e atividades criativas envolvendo tecnologia. ${ }^{55}$

${ }^{50}$ LOPES, Rodrigo T. Dias; GOMES, Larissa Rizzatti. Políticas públicas e museus no Estado de São Paulo: dos museus históricopedagógicos ao sistema estadual de museus. Educação, Batatais, v. 7, p. 49-63, jul./dez. 2017. p. 61.

51 POZZER, Marcio Rogerio Olivato. Políticas públicas para o patrimônio cultural na América Latina: a experiência brasileira e equatoriana e o papel do Banco Interamericano de Desenvolvimento. 2011. Dissertação (Mestrado em Integração da América Latina) - Integração da América Latina, Universidade de São Paulo, São Paulo, 2011. p. 105.

52 CANCLINI, Néstor García. Culturas híbridas: estratégias para entrar e sair da modernidade. 2. ed. São Paulo: Edusp, 1998.

${ }^{53}$ LOPES, Rodrigo T. Dias; GOMES, Larissa Rizzatti. Políticas públicas e museus no Estado de São Paulo: dos museus históricopedagógicos ao sistema estadual de museus. Educação, Batatais, v. 7, p. 49-63, jul./dez. 2017. p. 53-54.

54 Tipos de acervo: antropologia e etnografia; arqueologia; artes visuais; ciências naturais e história natural; ciência e tecnologia; história; imagem e som; virtual; biblioteconômico; documental; arquivístico. INSTITUTO BRASILEIRO DE MUSEUS. Museus em números. 2011. p. 70. Disponível em: http://www.museus.gov.br/ wp-content/uploads/2011/11/museus_em_numeros_volume1. pdf Acesso em: 23 jul. 2019.

55 SANTOS, Myrian Sepúlveda dos. Museus brasileiros e política cultural. Revista Brasileira de Ciências Sociais, São Paulo, v. 19, n. 55, p. 53-72, jun. 2004. p. 57-58. Disponível em: http://www.scielo.br/ scielo.php?script=sci_arttext\&pid=S010269092004000200004\&lng 
Para a modernização, ainda que tardia, e aperfeiçoamento da prática museológica no Brasil, foi elaborado por profissionais do setor, e aprovada no Congresso, a Lei n. ${ }^{\circ}$ 11.904, de 14 de janeiro de 2009, ${ }^{56}$ que instituiu o Estatuto de Museus. Nele há a definição de "museu" para a lei brasileira, ${ }^{57}$ que é muito próxima à definição de "museu", elaborada pelo International Council of Museums (ICOM). O Estatuto de Museus brasileiro é um importante documento, pois reúne, em um só marco legal, os princípios gerais para museus, obrigações e práticas de referência que devem ser adotadas pelos museus brasileiros quanto à estrutura, acervo e segurança aplicáveis aos museus públicos e àquelas instituições museológicas que queiram integrar o Sistema Brasileiro de Museus. Toda a atuação dos museus deve estar vinculada, por força dessa lei, ao Plano Nacional de Cultura.

Na Lei n.o 11.906, de 20 de janeiro de 2009, foi criado o Instituto Brasileiro de Museus (IBRAM) ${ }^{58}$ uma autarquia federal vinculada ao Ministério do Turismo ${ }^{59}$ e Secretaria Especial de Cultura. Nesse ato normativo, o IBRAM sucedeu ao Instituto do Patrimônio Histórico e Artístico Nacional (IPHAN) em todas as práti-

$=$ en\&nrm=iso Acesso em: 25 jul. 2019.

56 BRASIL. Lei $n^{\circ} 11.904$, de 14 de janeiro de 2009. Institui o Estatuto de Museus e dá outras providências. Disponível em: http://www. planalto.gov.br/ccivil_03/_ato2007-2010/2009/lei/111904.htm Acesso em: 23 jul. 2019.

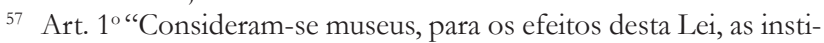
tuições sem fins lucrativos que conservam, investigam, comunicam, interpretam e expõem, para fins de preservação, estudo, pesquisa, educação, contemplação e turismo, conjuntos e coleções de valor histórico, artístico, científico, técnico ou de qualquer outra natureza cultural, abertas ao público, a serviço da sociedade e de seu desenvolvimento."

58 BRASIL. Lei no 11.906, de 20 de janeiro de 2009. Cria o Instituto Brasileiro de Museus - IBRAM, cria 425 (quatrocentos e vinte e cinco) cargos efetivos do Plano Especial de Cargos da Cultura [...]. Disponível em: http://www.planalto.gov.br/ccivil_03/_ato20072010/2009/lei/111906.htm Acesso em: 23 jul. 2019.

${ }^{59}$ Desvinculada do Ministério da Cidadania e Secretaria Especial de Cultura, passou a integrar a pasta do Ministério do Turismo, conforme teor do decreto n. ${ }^{\circ} 10.180$, de 7 de novembro de 2019, publicado no Diário Oficial em 8 de novembro de 2019. Passaram a se vincular ao Ministério Turismo, na mesma oportunidade, as seguintes entidades culturais, além do IBRAM: Agência Nacional do Cinema - ANCINE; Instituto do Patrimônio Histórico e Artístico Nacional - Iphan; Fundação Biblioteca Nacional - FBN; Fundação Casa de Rui Barbosa - FCRB; Fundação Cultural Palmares - FCP; e Fundação Nacional de Artes - FUNARTE. BRASIL. Decreto $n^{\circ}$ 10.108, de 7 de novembro de 2019. Anexo ao Decreto $\mathrm{n}^{\circ}$ 9.660 , de $1^{\circ}$ de janeiro de 2019 , que dispõe sobre a vinculação das entidades da administração pública federal indireta. Disponível em: http://www.planalto.gov.br/ccivil_03/_ato2019-2022/2019/decreto/D10108.htm Acesso em: 23 jul. 2019. cas referentes à atividade museológica; o IBRAM ficou responsável pela administração de vinte e três museus federais. Ambas as leis foram regulamentadas pelo Decreto n. ${ }^{\circ} 8.124,{ }^{60}$ de 17 de outubro de 2013. O IBRAM passou a ser o responsável pela coordenação do Sistema Brasileiro de Museus, inovando na prática museológica brasileira e sendo a principal entidade para o exercício museológico no país.

As finalidades do órgão não se referem a administrar ou centralizar a gestão de todos os museus públicos do país, mas, sim, em síntese: regular, fomentar e fiscalizar o setor museológico, coordenando e implementando o Plano Nacional Setorial de Museus e o Sistema Brasileiro de Museus; ou seja, promovendo uma gestão em rede entre todas as instituições do país que assim quiserem participar. O IBRAM deve, ainda, manter atualizadas as informações sobre os museus, bem como elaborar recomendações técnicas e realizar estudos e pesquisas sobre o setor, para que seja aperfeiçoada a aplicação das políticas públicas. ${ }^{61}$ Há como os museus se tornarem "associados" ao IBRAM se aceitos pelo Conselho Consultivo da instituição e podem ser associados ao IBRAM museus públicos e privados.

O Decreto n. ${ }^{\circ}$ 8.124/2013 regulamentou ferramentas criadas pelo Estatuto de Museus, até então inéditas no país, para ser possível conhecer o setor e mensurar o patrimônio cultural e bens musealizados, cabendo a atualização ser feita pelo IBRAM mediante: a) Registro de Museus; b) Cadastro Nacional de Museus; c) Inventário Nacional dos Bens Culturais Musealizados; e d) Cadastro Nacional de Bens Culturais Musealizados Desaparecidos. Foi estipulado como deve ser a gestão dos museus públicos e suas obrigações. $\mathrm{O}$ decreto previu que cada museu definirá o tipo de gestão, podendo optar por parcerias com o terceiro setor. Contudo, os dirigentes serão contratados por "processo público de seleção".

\footnotetext{
60 BRASIL. Decreto $n^{\circ} 8.124$, de 17 de outubro de 2013. Regulamenta Dispositivos da Lei $\mathrm{n}^{\circ}$ 11.904, de 14 de janeiro de 2009, que institui o Estatuto de Museus, e da Lei no 11.906, de 20 de janeiro de 2009, que cria o Instituto Brasileiro de Museus-IBRAM. Disponível em: http://www.planalto.gov.br/ccivil_03/_ato2011-2014/2013/decreto/d8124.htm Acesso em: 23 jul. 2019.

${ }^{61}$ POZZER, Marcio Rogerio Olivato. Políticas públicas para o patrimônio cultural na América Latina: a experiência brasileira e equatoriana e o papel do Banco Interamericano de Desenvolvimento. 2011. Dissertação (Mestrado em Integração da América Latina) - Integração da América Latina, Universidade de São Paulo, São Paulo, 2011. p. 141.
} 
Entre as criações normativas trazidas pelo Estatuto dos Museus, quando regulamentado pelo Decreto n. ${ }^{\circ}$ $8.124 / 2014$, a maior inovação foi o instituto jurídico declaração de interesse público de bens culturais, que possui paralelos com o clássico instituto brasileiro do Tombamento. O Estatuto de Museus, em seu artigo $5^{\circ}$, caput, em síntese, dispõe que os "bens culturais dos museus" podem ser declarados como de interesse público. $\mathrm{O} \$ 1^{\circ}$ explica "bens culturais passíveis de musealização" são todos aqueles "de interesse público", e "portadores de referência ao ambiente natural, à identidade, à cultura e à memória dos diferentes grupos formadores da sociedade brasileira." O $\$ 2^{\circ}$ explica que o acervo de museu "cuja proteção e valorização, pesquisa e acesso à sociedade representar um valor cultural de destacada importância para a Nação, respeitada a diversidade cultural, regional, étnica e linguística do País" será declarado como de interesse público.

Em razão dessas disposições da Lei n. ${ }^{o}$ 11.904/2009, nos artigos 35 e 36 do decreto regulamentador, foi instituída a competência do IBRAM (processo administrativo instaurado perante o presidente do IBRAM), submetida à homologação do então Ministro da Cultura após parecer do Conselho Consultivo do Patrimônio Museológico do IBRAM, a declaração de interesse público de bens culturais. Podem ser declarados os bens culturais musealizados e passíveis de musealização "cuja proteção e valorização, pesquisa e acesso à sociedade representarem valor cultural de destacada importância para o País, respeitada a diversidade cultural, regional, étnica e linguística." (art. 36).

Este é um novo instituto ainda pouco explorado doutrinariamente e até a época desta pesquisa ainda não fora utilizado. Os efeitos dessa declaração pelo IBRAM são muito semelhantes aos do tombamento do Decreto-Lei n..$^{\circ}$ 25/35. Contudo, por se tratar de bens móveis, e cuja mobilidade para exposições, circulação e venda é muito maior e dinâmica do que nos casos dos bens imóveis típicos do tombamento, a questão toma outros contornos. Embora o tombamento também recaia sobre bens móveis, o histórico da política demonstrou o predomínio da arquitetura no uso do instituto jurídico. ${ }^{62}$

62 INSTITUTO DO PATRIMÔNIO HISTÓRICO E ARTÍSTICO NACIONAL. Bens tombados e processos em andamento. Maio, 2019. Disponível em: http://portal.iphan.gov.br/uploads/ckfinder/arquivos/ BENS\%20TOMBADOS\%20E\%20PROCESSOS \%20EM\%20ANDAMENTO\%202019\%20MAIO.pdf Acesso em: 12 jul. 2019.
Por conta do acautelamento, os bens culturais ficariam impedidos de sair do país sem autorização e haveria outras restrições relativas ao uso e à circulação, $\mathrm{O}$ que afetaria, drasticamente, o mercado de obras de arte, até porque o instituto prevê o direito de preferência do IBRAM (e aos museus pertencentes ao Sistema Brasileiro de Museus - SBM) nos casos de alienação onerosa da obra acautelada.

O governo reconheceu obscuridades do Decreto n. ${ }^{\circ}$ 8.124/2014 e foi editada a Resolução Normativa n. ${ }^{\circ} 2$, de 29 de maio de 2019, para regulamentar a Declaração de Interesse Público de bens culturais musealizados ou passíveis de musealização, ${ }^{63}$ definindo o procedimento administrativo, prazos e esclarecendo conceitos pertinentes ao tema.

Muito embora o decreto não tenha previsto, em momento algum, uma desapropriação de obras de arte, de fato existem problemas quanto ao alcance, porque a Lei n. '11.904/2014 não se referiu às "coleções privadas", mas, sim, apenas, ao acervo de museu que apresenta valores relevantes para a nação. Contudo, a abrangência do decreto permaneceu, também, na resolução normativa que tentou disciplinar a matéria, entendendo como objeto desse acautelamento qualquer bem cultural móvel que seja possível ser, um dia, integrante de acervo de museu, por ser um national treasure.

Na realidade, existe mais uma importância simbólica do que prática no tocante ao novo instituto. Dado o contexto, observa-se que o art. 25 da resolução visa não gerar pânico em proprietários de coleções privadas. ${ }^{64}$ Por que o IBRAM se proporia a declarar tal interesse na obra, quando sua competência existe em relação ao acervo museológico ou futuramente musealizado? Uma possibilidade é a finalidade da catalogação. Preservação mediante localização da obra e controle de sua destinação e, por fim, o direito de preferência relativo à alienação onerosa do bem.

A coleção privada continuará no âmbito de fruição privada, mas, por ser obra de relevante valor para a nação, o

63 INSTITUTO BRASILEIRO DE MUSEUS. Resolução Normativa $n^{\circ}$ 2, de 29 de maio de 2019. Regulamenta a Declaração de Interesse Público de bens culturais musealizados ou passíveis de musealização. p. 4-6. Disponível em: https://www.in.gov.br/web/dou/-/resolucao-normativa-n-2-de-29-de-maio-de-2019-157603410 Acesso em: 23 jul. 2019. 64 Art. 25. A Declaração de Interesse Público prevista nesta Resolução Normativa não implica recolhimento do bem cultural para instituição museológica, pública ou privada, nem exclui a responsabilidade dos seus proprietários ou responsáveis legais pela sua regular preservação, respeitados sempre os direitos inerentes à propriedade. 
Estado saberá onde essa obra estará enquanto ela existir. Se o dono desaparecer com a obra, em tese, o Estado deve tomar conhecimento do fato - pois cabe a ele fiscalizar a obra acautelada - e aplicar alguma sanção a ser regulamentada futuramente. ${ }^{65}$ No caso em que o particular quiser se desfazer da obra, o Estado, ou algum dos museus do Sistema Brasileiro de Museus (que pode ser de natureza privada), pode comprar a obra em regime de preferência e, assim, expor para o público ter acesso em solo brasileiro do seu reconhecido patrimônio cultural. Todavia, ainda que criado para aprimorar um sistema de proteção de bens culturais, o instituto pode se tornar inócuo se não forem utilizados critérios comprometidos com o real interesse público insculpido no bem cultural, um interesse público em sentido estrito, equivalente a um interesse da coletividade em si, mas que somente se faz possível identificar no caso concreto. ${ }^{66}$ Nesse caso, a supremacia do interesse público decorre de valores incorporados na Constituição e objetivos da República do Brasil. ${ }^{67}$

\section{Internacionalização da proteção de acervos aos museus}

\subsection{O Conselho Internacional de Museus (ICOM)}

A preocupação comum com a preservação dos testemunhos da civilização humana, ${ }^{68}$ com o espaço

\footnotetext{
${ }^{65}$ Decreto 8.124/2014 prevê processo administrativo sancionar em desfavor de quem descumprir as obrigações do acautelamento do bem declarado de interesse público. Na Resolução Normativa n. ${ }^{\circ}$ 2/2019 foi exposto que as penalidades atinentes seriam regulamentadas em ato posterior. BRASIL. Decreto $n^{\circ} 8.124$, de 17 de outubro de 2013. Regulamenta Dispositivos da Lei $\mathrm{n}^{\circ} 11.904$, de 14 de janeiro de 2009, que institui o Estatuto de Museus, e da Lei n ${ }^{\circ} 11.906$, de 20 de janeiro de 2009, que cria o Instituto Brasileiro de MuseusIBRAM. Disponível em: http://www.planalto.gov.br/ccivil_03/_ ato2011-2014/2013/decreto/d8124.htm Acesso em: 23 jul. 2019.

${ }^{66}$ HACHEM, Daniel Wunder. A dupla noção jurídica de interesse público em direito administrativo. A\&C - Revista de Direito Administrativo \& Constitucional, Belo Horizonte, ano 11, n. 44, p. 59-110, abr./jun. 2011. p. 69.

${ }^{67}$ GABARDO, Emerson; REZENDE, Maurício Corrêa de M. O conceito de interesse público no direito administrativo brasileiro. Revista Brasileira de Estudos Políticos, Belo Horizonte, n. 115, p. 267318, jul./dez. 2017. p. 307; GABARDO, Emerson. O princípio da supremacia do interesse público sobre o interesse privado como fundamento do direito administrativo social. Revista de Investigaçōes Constitucionais, Curitiba, v. 4, n. 2, p. 95-130, maio/ago. 2017.

68 ALMEIDA, Eneida de. O "construir no construido" na produção contemporânea: relações entre teoria e prática. 2009. Tese (Doutorado em
}

urbano, ${ }^{69}$ construções históricas, bem como a necessidade de conscientização e educação a esse respeito moveu profissionais e estudiosos da arquitetura e técnicos de monumentos históricos a realizarem congressos internacionais cujas deliberações deram origem ao documento Carta de Atenas, em 1931. ${ }^{70}$ A colaboração internacional passou a integrar a pauta sobre a propriedade cultural e a preservação histórica. Segundo o novo pensamento, a respeito do tema, as construções antigas devem ser protegidas pelos Estados Nacionais, que devem colaborar entre si para conservar e restaurar seus monumentos históricos. ${ }^{71}$ Este foi o primeiro movimento de inclusão da preocupação com vestígios históricos e artísticos em uma pauta de interesse da comunidade internacional que estava se desenvolvendo. Recomendava-se a criação de instituições qualificadas para operar com esse propósito e auxiliar as nações comprometidas, sobretudo aquelas que fizessem parte da Sociedade (ou Liga) das Nações. Essa carta deu origem à criação do Escritório Internacional de Museus. ${ }^{72}$ Todavia, o Escritório Internacional de Museus encerrou suas atividades em 1939, em razão da Segunda Guerra Mundial. O Conselho Internacional de Museus (ICOM) pode ser considerado como herdeiro desta instituição. ${ }^{73}$

Arquitetura e Urbanismo) - Universidade de São Paulo, São Paulo, 2009. p. 62.

69 TALLER, Adriana. Derecho a la preservación del patrimonio arquitectónico urbano: un desafío para las autoridades locales. Revista Eurolatinoamericana de Derecho Administrativo, Santa Fé, v. 1, n. 2, p. 7-37, jul./dez. 2014; TALLER, Adriana. Los instrumentos de gestión urbana promotores de los derechos económicos, sociales culturales y ambientales. Revista Eurolatinoamericana de Derecho Administrativo, Santa Fé, v. 5, n. 1, p. 5-28, jan./jun. 2018.

70 INSTITUTO DO PATRIMÔNIO HISTÓRICO E ARTÍSTICO NACIONAL. Carta de Atenas (1931). Disponível em: http:// portal.iphan.gov.br/uploads/ckfinder/arquivos/Carta $\% 20 \mathrm{de} \% 20$ Atenas\%201931.pdf Acesso em: 2 de jul. 2020; outro documento importante nesta seara foi a Carta de Veneza (1964), que mudou substancialmente a abordagem na tratativa de bens culturais, deixando a "excepcionalidade" do monumento um critério para conservação. INSTITUTO DO PATRIMÔNIO HISTÓRICO E ARTÍSTICO NACIONAL. Carta de Veneza (1964). Disponível em: http://portal.iphan.gov.br/uploads/ckfinder/arquivos/Carta $\% 20$ de\%20Veneza\%201964.pdf Acesso em: 2 jul. 2020.

71 CONSEIL INTERNACIONAL DES MONUMENTS ET DES SITES. Historique. Disponível em: https://www.icomos.org/ $\mathrm{fr} / \mathrm{a}$-propos-de-licomos/mission-et-vision/historique. Acesso em: 2 jul. 2021.

72 ALMEIDA, Eneida de. O "construir no construido" na produção contemporânea: relações entre teoria e prática. 2009. Tese (Doutorado em Arquitetura e Urbanismo) - Universidade de São Paulo, São Paulo, 2009. p. 62.

73 LIMA, Diana Farjalla Correia. Museologia-Museu e patrimônio, patrimonialização e musealização: ambiência de comunhão. Boletim do Museu Paraense Emílio Goeldi - Ciências Humanas, Belém, v. 7, n. 1, p. 
O ICOM é uma organização não governamental que teve origem no contexto da tensão posterior à Segunda Guerra Mundial, em 1946, quando havia forte demanda pela comunidade internacional em reconstruir danos sociais e instituições culturais devastadas pela guerra, no mesmo contexto sociopolítico de criação da UNESCO, em $1945 .{ }^{74}$ Embora haja forte relação de colaboração entre elas, o ICOM sempre foi uma organização autônoma e de natureza privada, enquanto a UNESCO é uma organização intergovernamental.

Inicialmente, o ICOM era um pequeno grupo de representantes de museus de diferentes partes do mundo, e sua missão de criação foi "para buscar programas de cooperação internacional diretamente por meio de suas redes profissionais em uma base de museu a museu". ${ }^{75}$ O ICOM possui há décadas prestígio internacional e tem papel consolidado ao promover uma integração global das instituições museológicas. ${ }^{76}$ Estipula metas e diretrizes; promove eventos e conferências com autoridades acadêmicas e de gestão do setor para discussão de temas sensíveis e debater soluções e modernização; ${ }^{77}$ expede recomendações e cria normas regulamentadoras; promove capacitações, programas de cooperação dentre os membros. Estes participam por meio de associação (membership association) e os países podem formar comitês nacionais, como é o caso do Brasil, que tem o comitê nacional desde $1948 .^{78}$ A natureza civil do Comitê Brasileiro é associação civil sem fins lucrativos. ${ }^{79}$ Hoje o ICOM é a única associação global no

31-50, jan./abr. 2012. p. 41.

${ }^{74}$ MURPHY, Bernice L. Charting the ethics landscape for museums in a changing world. In: MURPHY, Bernice L. (ed.). Museums, ethics and cultural heritage. Londres; Nova York: Routledge, 2016. p. 20. 75 No original: "to pursue programs of international cooperation directly through its professional networks on a museum-to-museum basis". MURPHY, Bernice L. Charting the ethics landscape for museums in a changing world. In: MURPHY, Bernice L. (ed.). Museums, ethics and cultural heritage. Londres; Nova York: Routledge, 2016. p. 20. Tradução livre.

${ }^{76}$ HERSCHER, Ellen. The antiquities market: news and commentary on the illicit traffic on antiquities. Journal of Field Archaeology, v. 14, n. 2, p. 213-223, jun./set. 1987. p. 215.

${ }^{77}$ THOMPSON, Hilary H. International law, and its vision of the ideal museum. Curator: The Museum Journal, v. 51, n. 1, p. 5-10, jan. 2008. p. 6.

78 COMITÊ BRASILEIRO DO CONSELHO INTERNACIONAL DE MUSEUS. O ICOM Brasil. Disponível em: https://www. icom.org.br/?page_id=12 Acesso em: 5 jun. 2021.

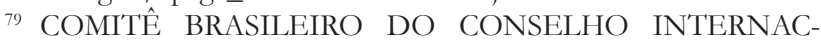
IONAL DE MUSEUS. Estatuto Social do Comitê Brasileiro do Conselho Internacional de Museus. Disponível em: http://www.icom.org.br/wpcontent/uploads/2013/05/Estatuto-ICOM-BR.pdf Acesso em: 5 jun. 2021. campo museológico, possui 44.686 profissionais associados, de 138 países; 118 comitês nacionais, 32 comitês internacionais, ${ }^{80}$ e 6 alianças regionais. ${ }^{81}$

Existem 31 comitês internacionais temáticos do ICOM ${ }^{82}$ que representam as áreas de atuação da museologia na atualidade e são "instâncias de legitimidade cultural" nos respectivos campos. ${ }^{83}$ Os comitês ${ }^{84}$ e seus respectivos membros se dedicam ao estudo de cada tipo de museu e suas disciplinas, ao desenvolvimento científico e trocas de experiências entre profissionais do mundo todo, na respectiva área. Cada membro do ICOM precisa estar associado a um comitê temático de sua escolha e tem direito a um voto nas deliberações da instituição. O ICOM elabora documentos normativos que se destinam a regulamentar as ações de seus membros e todos os envolvidos na prática museológica, sendo estas as regras internas, o seu Estatuto e o Código de Ética. Este é considerado a "pedra angular" do ICOM. ${ }^{85}$ Sua criação foi em 1986, e última revisão em 2004, aprovada em Assembleia Geral em Seul, após seis anos de discussões e revisões para chegar no texto atualizado.

\subsection{Para uma museologia ética}

O Código de ética do ICOM, considerado por autores como de clareza e especificidade notáveis, ${ }^{86}$ traz princípios éticos, critérios e padrões para guiar as ações do profissional de museus no exercício de suas funções laborais, bem como de todas as pessoas que atuem direta ou indiretamente com museus, sempre em benefício

80 INTERNATIONAL COUNCIL OF MUSEUM. Home. Disponível em: https://icom.museum/en/ Acesso em: 25 jun. 2021. 81 INTERNATIONAL COUNCIL OF MUSEUM. Home. Disponível em: https://icom.museum/en/ Acesso em: 25 jun. 2021.

82 COMITE BRASILEIRO DO CONSELHO INTERNACIONAL DE MUSEUS. Comitês Internacionais. Disponível em: https:// www.icom.org.br/?page_id=6 Acesso em: 25 jun. 2021.

83 LIMA, Diana Farjalla Correia. Museologia-Museu e patrimônio, patrimonialização e musealização: ambiência de comunhão. Boletim do Museu Paraense Emílio Goeldi - Ciências Humanas, Belém, v. 7, n. 1, p. 31-50, jan./abr. 2012.

84 INTERNATIONAL COMMITTEE FOR MUSEOLOGY. Home. Disponível em: http://icofom.mini.icom.museum/ Acesso em: 25 jun. 2021.

85 COMITÊ BRASILEIRO DO CONSELHO INTERNACIONAL DE MUSEUS. Versão Lusófona do Código de Ética para Museus ICOM. Disponível em: http://icom.org.br/wpcontent/themes/ colorwaytheme/pdfs/codigo $\% 20 \mathrm{de} \% 20$ etica/codigo_de_etica_lusofono_iii_2009.pdf Acesso em: 6 jun. 2021.

86 HERSCHER, Ellen. The antiquities market: news and commentary on the illicit traffic on antiquities. Journal of Field Archaeology, v. 14, n. 2, p. 213-223, jun./set. 1987. p. 214. 
de toda a sociedade. ${ }^{87}$ Segundo seus padrões éticos, no conflito de interesses entre o museu (de dimensão coletiva) e interesses individuais nas exposições, o interesse do museu deve prevalecer. ${ }^{88}$ Esse tipo de regramento e sua observação se fazem de suma importância, porque a ética, na seara museológica, se relaciona tanto com elementos teóricos da filosofia da conduta quanto a aspectos práticos, que Edson Gary chama de "critical contemporary issues". Essas questões seriam, ilustrativamente, "a aquisição de artefatos, os direitos dos indígenas, a repatriação, as políticas de exibição, [...] bem como a gestão cotidiana de um museu". ${ }^{9}$

As normas do ICOM são vinculantes aos filiados da instituição, mas, atualmente, exercem influência, de maneira proeminente, no campo museológico mundial, assumindo prestígio e reconhecimento que vai além da sua membresia. Atualmente, a definição de museu elaborada pelo ICOM e seu Código de Conduta é referência universal na gestão de museus e patrimônio cultural, assumindo um novo papel no Direito interno de países ao redor do mundo e, também, no Direito internacional. ${ }^{90}$

Tamanha é a sua influência, que sua definição de museu foi incluída no parágrafo 4 da Recomendação Referente à Proteção e Promoção dos Museus e Coleções, sua Diversidade e seu Papel da Sociedade, ${ }^{91}$ de 20 de novembro de 2015, da UNESCO; a única Recomendação exclusiva sobre museus após 55 anos desde a primeira editada, em 1960. Ainda, no parágrafo 26 da Recomendação, o Código de Ética do ICOM é mencionado como um texto de referência e seus termos devem

\footnotetext{
${ }^{87}$ FRIGO, Manlio. Ethical rules and codes of honor related to museum activities: a complementary support to the private international law approach concerning the circulation of cultural propert. International Journal of Cultural Property, v. 16, n. 1, p. 49-66, fev. 2009. ${ }^{88}$ CAPONIGRI, Felicia. The ethics of the international display of fashion in the museum. Case Western Reserve Journal of International Law, Cleveland, v. 49, n. 1, 2017. p. 137.

${ }^{89}$ No original: "the procurement of artefacts, the rights of Indigenous people, repatriation, the politics of display [...], as well as the day-to-day management of a museum". EDSON, Gary. Unchanging ethics in a changing world. In: MURPHY, Bernice L. (ed.). Museums, ethics and cultural heritage. Londres; Nova York: Routledge, 2016.

${ }^{90}$ GARLANDINI, Alberto. ICOM's museum definition, code of ethics, and policy in favour of museums and heritage. In: SYMPOSIUM ICOFOM Defining the Museum of the 21st century, 2017, St Andrews: defining museums of the 21 st century: plural experiences. Paris: ICOM/ICOFOM, 2018. p. 169.

91 UNESCO. Report on the implementation of the UNESCO 2015 Recommendation on Museums \& Collections. Paris, 2019. Disponível em: http://inclusivemuseums.org/wp-content/ uploads/2019/11/781371549eng.pdf Acesso: 14 jul. 2020.
}

ser adotados e disseminados pelos Estados-Membros, visando ao desenvolvimento de suas políticas e legislação nacional sobre o tema. ${ }^{92}$

A partir da Resolução 2015 para museus da UNES$\mathrm{CO}^{93}$, visando a sua implementação, foi criado, em 2016, um novo órgão consultivo do Diretor-Geral da UNESCO, o High Level Fórum on Museums. No encontro de inauguração do órgão, em Shenzhen, China, foi elaborada uma declaração, ${ }^{94}$ em que se reforçou o compromisso com as boas práticas que guiarão as ações da UNESCO para políticas do setor, sempre em consonância com o Código de Ética do ICOM, além de encorajar que os Estados-Membros adotem rigorosos códigos de ética, baseando-se nas suas instruções.

A Itália é um exemplo de país onde o Código de Ética do ICOM é vinculante e teve sua força normativa reconhecida, a partir da reforma do decreto ministerial sobre State Museums em 2014..$^{95}$ A lei nacional fez uma cópia literal da definição e missão dos museus adotada pelo Estatuto do ICOM e também estipula que os estatutos dos museus nacionais devem estar em consonância com o Código de Ética do ICOM, bem como todos os seus padrões, para, então, estarem de acordo com a legalidade em solo italiano.

Assim, o ICOM é um exemplo de organização privada internacional de autorregulação que opera em nível global, semelhante a organizações como o Comitê Olímpico Internacional, ou o International Organization for Standardization (ISO em português). Lorenzo Casini conclui que uma possível origem desse fenômeno de autorregulação de setores por atores não estatais, como

92 GARLANDINI, Alberto. ICOM's museum definition, code of ethics, and policy in favour of museums and heritage. In: SYMPOSIUM ICOFOM Defining the Museum of the 21st century, 2017, St Andrews: defining museums of the 21st century: plural experiences. Paris: ICOM/ICOFOM, 2018. p. 170.

93 UNESCO. Recommendation concerning the Protection and Promotion of Museums and Collections, their Diversity, and their Role. 2015. Disponível em: http://www.unesco.org/new/en/culture/themes/museums/ recommendation-on-the-protection-and-promotion-ofmuseumsand-collections/ Acesso: 14 jul. 2020.

94 UNESCO. Shenzhen Declaration on Museums and Collections. High Level Forum on Museums, Shenzhen, 10 de 12 November 2016. Disponível em: http://www.unesco.org/new/fileadmin/MULTIMEDIA/HQ/CLT/pdf/Shenzhen_Declaration-en.pdf Acesso em: 14 jul. 2020.

${ }^{5}$ GARLANDINI, Alberto. ICOM's museum definition, code of ethics, and policy in favour of museums and heritage. In: SYMPOSIUM ICOFOM Defining the Museum of the 21st century, 2017, St Andrews: defining museums of the 21st century: plural experiences. Paris: ICOM/ICOFOM, 2018. p. 173. 
o ICOM, foi uma maneira de compensar a falta de normas em nível global. No caso específico do ICOM, a aceitação de suas normas como legítimas, inclusive por Estados, se justificaria em razão do alto nível de expertise profissional. ${ }^{96} \mathrm{Ou}$ seja, a missão pública dos museus, bem como a natureza também pública de muitos dos seus membros.

\subsection{Softlaw e museus globalizados}

A natureza do Código de Ética do ICOM pode ser entendida como soft law, espécie de norma que, inclusive, em relação ao combate aos crimes internacionais envolvendo obras de arte e bens culturais, vem assumindo protagonismo nos últimos anos. ${ }^{97}$

O "soft law" é uma categoria doutrinária que admite a existência de regras de conduta que, embora não tenham força legal vinculante, possuem efeitos práticos nos comportamentos institucionais; ${ }^{98}$ são resoluções não vinculantes que lembram regulações legais, mas são elaboradas fora de uma estrutura tradicional de elaboração de leis; e o fato de não estarem vinculadas a uma sanção direta pelo eventual descumprimento é o que as caracteriza como "soff'. São contrapostas, portanto, ao modelo tradicional de "hard law", que seria exigível imediatamente, criado pelo Estado, associado a uma sanção direta e objetivamente prevista pelo seu descumprimento. Podem estar dentro do alcance do termo soft law os códigos de conduta internacionais, princípios gerais, diretrizes, políticas, recomendações e convenções não ratificadas, a título de exemplo. ${ }^{99}$

Representam, contudo, espécie de "cooperação informal tão cogente quanto tratados" em setores nos quais se visa a uma harmonização da tratativa da matéria, ${ }^{100}$ como é o caso das normas de proteção de

96 CASINI, Lorenzo. "Italian Hours": the globalization of cultural property law. International Journal of Constitutional Law, v. 9, n. 2, p. 369-393, abr. 2011.

97 FRANCA FILHO, Marcílio Toscano; VALE, Matheus C. do; SILVA, Nathálya L. da. Mercado de arte, integridade e due diligence no Brasil e no Mercosul cultural. Revista de la Secretaría del Tribunal Permanente de Revisión, ano 7, n. 14, p. 260-282, ago. 2019. p. 266.

98 SNYDER, Francis. The Effectiveness of European Community Law: Institutions, Processes, Tools and Techniques. The Modern Law Review, v. 56, n. 1, p. 19-54, jan. 1993. p. 32.

99 VAN DER SLUIJS, Jessika. Soft law - an international concept in a national context. Scandinavian Studies in Law, v. 58, p. 285-306, dez. 2013. p. 286-287.

100 SOUZA, Leonardo da Rocha de; LEISTER, Margareth Anne. A influência da soft law na formação do direito ambiental. Brażilian bens culturais, em sede de museus ou não. Gunther Teubner, ao explorar as características de uma soft law, defende que sua "suavidade" não é uma fraqueza, mas sim uma virtude. Uma vez mais flexível e adaptável às mudanças de circunstâncias, passa, paradoxalmente, a ser mais resistente a "destruições simbólicas" em casos de desvio, além de favorecer cenários de unificação global e aplicabilidade global, sendo branda, mas não por isso fraca. ${ }^{101}$

Uma das características que se repetem nas variadas manifestações de soft law, seja no Direito interno ou no campo do Direito internacional, é o fato de essas normas serem criadas por organizações com autoridade reconhecida sobre o assunto a que se propõem regular.

Ademais, há quem se comprometa em seguir essas normas, reconhecendo tal autoridade. O soft law possui uma força normativa implícita que visa orientar as ações dos destinatários e, embora não haja sanções previstas explicitamente, o descumprimento pode gerar punições espontâneas e imprevisíveis, como a má publicidade ou má reputação no âmbito interno e externo político. $\mathrm{O}$ descumprimento pode, ainda, prejudicar relações com outros Estados que aceitaram e cumprem aquela norma ou, ainda, o descumpridor pode deixar de receber incentivos destinados àqueles que cumprem a norma. ${ }^{102}$ O que vai fazer com que uma norma de soft law seja elaborada, e funcione como se uma regra legal (de Direito positivo) fosse, é a existência de sólida base de " $u n$ derstandings shared" da respectiva comunidade a que se destina. Isso tende a gerar um senso de obrigação em seguir esta norma, independentemente da existência de sanções objetivas. ${ }^{103}$

Existem duas correntes que pleiteiam para si a genealogia do soft law: a que acredita que essas normas são ancestrais do pluralismo jurídico medieval e a lex mercatoria; e aqueles que relacionam o soft law às noções de Direito social e pluralismo jurídico desenvolvido por juristas europeus anti-formalistas no final do século XIX em diante. Os filiados à segunda corrente defendem

Journal of International Law, Brasília, v. 12, n. 2, 2015.

101 TEUBNER, Gunther. Global bukowina: legal pluralism in the world-society. In: TEUBNER, Gunther (ed.). Global law without a state. Dartmouth: Aldershot, 1997. p. 3-28. p. 16.

102 VAN DER SLUIJS, Jessika. Soft law - an international concept in a national context. Scandinavian Studies in Law, v. 58, p. 285-306, dez. 2013. p. 286, 288-289.

103 ELLIS, Jaye. Shades of grey: soft law and the validity of public international law. Leiden Journal of International Law, Cambridge, v. 25, n. 2, p. 313-334, 2012. p. 325. 
a aplicação da soft law para projetos que implementem uma nova visão política que una eficiência, solidariedade, flexibilidade, segurança. No contexto da comunidade europeia, ${ }^{104}$ são aqueles teóricos comprometidos com a agenda social no bloco e que defendem o modelo de Estado de bem-estar social adotado tradicionalmente por países europeus. ${ }^{105}$

No Direito internacional público, o desenvolvimento doutrinário para a adoção do soft law se deve, em muito, à Declaração Universal de Direitos Humanos de 1948, ${ }^{106}$ aceita pela Assembleia Geral da ONU. Isto porque a natureza jurídica do documento não se enquadrava, formalmente, nas fontes do Direito tradicionais elencadas no artigo 38 da Corte Internacional de Justiça, ${ }^{107}$ que eram as utilizadas para decidir controvérsias apresentadas. É inegável a importância jurídica daquele documento para a matéria de Direitos Humanos em escala global. ${ }^{108}$

Jaye Ellis explica que na doutrina podem ser encontradas diferentes categorias de soft law e, das descritas

104 ROBILANT, Anna di. Genealogies of Soft Law. The American Journal of Comparative Law, v. 54, n. 3, p. 499-554, jul. 2006. p. 219-223. Disponível em: https://www.researchgate.net/publication/256003377_Genealogies_of_Soft_Law Acesso em: 20 jun. 2020 .

105 Sobre sistema normativo comunitário da União Européia ver: FRANCA FILHO, Marcílio Toscano. As diretivas da Comunidade Européia: elementos para uma teoria geral. Revista de Direito Constitucional e Internacional, ano 9, n. 37, p. 7-26, out./dez. 2001; UNIÃO EUROPEIA. European Commission. Disponível em: https://europa. eu/european-union/about-eu/institutions-bodies/european-commission_en Acesso em: 11 jul. 2020.

${ }^{106}$ BRUS, Marcel M. J. A. Soft law in public internacional: a pragmatic or a principle choice? comparing the sustainable development goals and the Paris Agreement. In: WESTERMAN, Pauline et al. (eds.). Legal validity and soft law. Nova York: Springer, 2018. p. 243266. p. 248.

107 Article 38. The Court, whose function is to decide in accordance with international law such disputes as are submitted to it, shall apply: a. international conventions, whether general or particular, establishing rules expressly recognized by the contesting states; $b$. international custom, as evidence of a general practice accepted as law; c. the general principles of law recognized by civilized nations; d. subject to the provisions of Article 59, judicial decisions and the teachings of the most highly qualified publicists of the various nations, as subsidiary means for the determination of rules of law. ORGANIZAÇÃO DAS NAÇÕES UNIDAS. Statute of The International Court of Justice - ICJ. São Francisco, 26 de junho de 1945. Disponível em: https://www.icj-cij.org/en/statute Acesso em: 13 jul. 2020.

108 BRUS, Marcel M. J. A. Soft law in public internacional: a pragmatic or a principle choice? comparing the sustainable development goals and the Paris Agreement. In: WESTERMAN, Pauline et al. (eds.). Legal validity and soft law. Nova York: Springer, 2018. p. 243266. p. 248. pela autora, ${ }^{109}$ duas se destacam por serem encontradas no sistema normativo global de proteção aos museus e seus acervos: normas não vinculantes, mas obrigações políticas e morais adotadas pelos Estados - exemplo é a Resolução 2015 da UNESCO para museus; e normas promulgadas por atores não estatais — como é o Código de Ética do ICOM.

A especificidade das normas do ICOM, ainda que reconhecidas como soft law, apresenta um desafio no campo do Direito internacional público, pois sua validade não parte do consentimento estatal, ${ }^{110}$ elemento fundante da concepção voluntarista e positivista clássica das fontes do Direito internacional. ${ }^{111}$ O Código de Ética não é uma convenção internacional como as elaboradas pela UNESCO, que envolve a discussão e possibilidade de anuência, ou não, do Estado-Membro, e depois com a possibilidade ou não da recepção daquele tratado no Direito interno por meio da ratificação e promulgação. ${ }^{112}$

A existência do ICOM e sua função regulamentadora criadora de normas é retrato de um fenômeno crescente, associado ao tema da soft law, de "legisladores privados", o que Gunther Teubner chama de "governança privada" (private government). Mas essas normas teriam a legitimidade resguardada em razão do teor altamente público de seu conteúdo, como nos casos da padronização técnica, de produção profissional, regulação intraorganizacional, em direitos humanos e em contratos internacionais, por exemplo. Esse novo cenário global também impõe novos desafios e a busca de novas formas de legitimação democrática para levar estas ações nos campos econômico, profissional e técnico perante métodos de avaliação públicos e que sejam os resultados controláveis de alguma maneira. ${ }^{113}$ Para Benedict

109 ELLIS, Jaye. Shades of grey: soft law and the validity of public international law. Leiden Journal of International Law, Cambridge, v. 25, n. 2, p. 313-334, 2012. p. 315.

110 Sobre fundamentos do Direito Internacional contemporâneo, ver: JUBILUT, Liliana Lyra. Os fundamentos do direito internacional contemporâneo: da coexistência aos valores compartilhados. Anuário Brasileiro de Direito Internacional, Belo Horizonte, v. 2, n. 9, p. 203-219, 2010.

111 ELLIS, Jaye. Shades of grey: soft law and the validity of public international law. Leiden Journal of International Law, Cambridge, v. 25, n. 2, p. 313-334, 2012. p. 313.

112 BRASIL. Câmara dos Deputados. A tramitação dos atos internacionais no Congresso Nacional. Disponível em: https://www2.camara. leg.br/atividade-legislativa/estudos-e-notas-tecnicas/publicacoesda-consultoria-legislativa/copy_of_portas-abertas-1/Palestra9.pdf Acesso em: 13 jul. 2020.

113 TEUBNER, Gunther. Breaking frames: economic globalisation 
Kingsbury, o fenômeno de uma governança global cada vez mais descentralizada e conectada (com instituições transnacionais, órgãos híbridos público-privados, ou de natureza privada de alcance global), está cada vez mais afetando decisões administrativas de Estados nacionais. Há o que o autor e outros doutrinadores chamam de um "Direito administrativo global" e não haveria como ignorar esse novo cenário. ${ }^{114}$

Essas novas relações demandam dos agentes envolvidos, nos processos de tomadas decisão, a transparência, consulta, processos de participação, racionalidade, mecanismos de revisão e accountability. A capacidade de criar leis não se limitaria à centralidade do Estado, mas as normas desses atores não estatais na seara internacional deveriam seguir princípios gerais do Direito público, sintetizado pelo autor na ideia de "publicness", passando a ser um fundamento de validade dessas normas não estatais. Em rol não taxativo, a noção do autor desse caráter público das normas de atores não estatais deveria englobar o Princípio da Legalidade, racionalidade, proporcionalidade, rule of law e respeito aos direitos humanos. ${ }^{115}$

A função administrativa e regulamentadora do ICOM, muito embora não seja um agente estatal, influencia, diretamente, a ação de Estados nacionais, causando uma verdadeira confluência de normas internas e internacionais, sendo esta uma tendência crescente apontada por autores como Kingsbury e Nico Krisch. $\mathrm{Na}$ linha defendida por tais autores, admitindo-se a existência de um Direito administrativo global, o consentimento estatal, em alguma medida, perderia espaço. Entretanto, também se observa o movimento de aceitação no Direito interno de práticas e fontes normativas advindas de acordos institucionais informais, inclusive com a participação de atores não estatais, que não estão dentro de um conceito tradicional de Direito internacional. ${ }^{116}$

and the emergence of lex mercatoria. European Journal of Social Theo$r y$, v. 5, p. 199-217, 2002. p. 207-208.

114 KINGSBURY, Benedict. The concept of 'law' in global administrative law. European Journal of International Law, Oxford, v. 20, n. 1, p. 23-57, fev. 2009. p. 25.

115 KINGSBURY, Benedict. The concept of 'law' in global administrative law. European Journal of International Law, Oxford, v. 20, n. 1, p. 23-57, fev. 2009. p. 2-33.

${ }_{116}$ KRISCH, Nico; KINGSBURY, Benedict. Introdução: governança global e direito administrativo global na ordem legal internacional. RDA - Revista de Direito Administrativo, Rio de Janeiro, v. 261, p. 13-32, set. 2012. p. 17-20.
O denominado "Direito administrativo global" é mais amplo que uma mera internacionalização do Direito administrativo estatal, pois se trata de uma diferença de fonte normativa e extensão. $O$ fenômeno do Direito administrativo global tem o potencial de impacto genérico a todos os países e se refere a circunstâncias fáticas quando o direito nacional não é capaz de abarcar toda a matéria de um segmento, cabendo ao Estado se basear e se auto vincular às normas externas reguladoras $\mathrm{e}$ criadas por outros agentes que não Estados. ${ }^{117}$ Portanto, é possível afirmar que "Direito administrativo internacional" não é um sinônimo, sendo este o Direito criado pelo próprio Estado para regular suas relações jurídicas com agentes estrangeiros.

\section{Paralelos e dissonâncias teóricas entre normas gerais brasileiras para museus e o Código de Ética Internacional}

As políticas de cultura elaboradas no Brasil, a partir dos novos comandos da Constituição de 1988, são fruto de esforços institucionais para mapear a situação nacional da produção, difusão, acesso e proteção cultural dos bens culturais brasileiros. Esses projetos se desenvolveram ao longo da primeira década dos anos 2000, de maneira sistemática e coordenada dentro do âmbito do extinto Ministério da Cultura.

No Plano Nacional de Cultura (Lei n. $\left.{ }^{\circ} 12.343 / 2010\right)$, de duração de 10 anos, vigente até 2020, foi dada atenção especial ao setor museológico, com a sistematização da matéria legal, determinando as bases para a prática museológica no país através das principais normas gerais: Estatuto de Museus (Lei n. $\left.{ }^{\circ} 11.904 / 2009\right)$; Lei de Criação do Instituto Brasileiro de Museus - IBRAM (Lei n. ${ }^{\circ}$ 11.906/2009); Decreto n. ${ }^{\circ} 8.124 / 2013$ (regulamenta as leis n. ${ }^{\circ} 11.904 / 2009$ e n. $\left.{ }^{\circ} 11.906 / 2009\right)$. A aplicação dos princípios fundamentais dos museus, ${ }^{118}$

\footnotetext{
17 SILVA, Alice R. da; SANTOS, Ruth Maria. P dos. As diretivas europeias como norma reguladora do direito administrativo global. Brazilian Journal of International Law, Brasília, v. 13, n. 3, 2016. p. 360 361.

118 Art. $2^{\circ}$ São princípios fundamentais dos museus: I - a valorização da dignidade humana; II - a promoção da cidadania; III - o cumprimento da função social; IV - a valorização e preservação do patrimônio cultural e ambiental; V - a universalidade do acesso, o respeito e a valorização à diversidade cultural; VI - o intercâmbio
} 
por força da lei do Estatuto, deve estar vinculada aos princípios basilares do Plano Nacional de Cultura, ${ }^{119}$ bem como do regime de proteção e valorização do patrimônio cultural. Há, portanto, íntima relação entre as leis museológica e o Plano Nacional de Cultura.

O Estatuto de Museus consolida o Sistema de museus, destinado aos entes federativos e gestão dos museus públicos, para que formem seus próprios sistemas em nível local. Esses museus devem colaborar e podem participar do Sistema Brasileiro de Museus (SBM), que passou a ser coordenado pelo IBRAM, por força de sua lei de criação. Ainda, nos termos do Estatuto, consta que, nesse sistema, podem participar museus públicos, privados e instituições educacionais relacionadas à área da museologia e as entidades afins, na forma da legislação específica. ${ }^{120}$

Uma especial inovação é o fato de o SBM ser formado por Comitê Gestor, composto por representantes de órgãos e entidades com representatividade na área da museologia nacional. ${ }^{121} \mathrm{E}$ não há distinção entre a natureza jurídica dessas instituições, se pública ou privada. No decreto regulamentador do Estatuto (Decreto n. ${ }^{\circ}$ $8.124 / 2013)$, consta que entre as entidades que comporão a gestão do Sistema Brasileiro de Museus está o Comitê Brasileiro do ICOM, por meio de um representante da instituição. ${ }^{122}$

Dessa forma, há reconhecimento explícito na lei brasileira da autoridade do ICOM para o setor museológico nacional. Ressalta-se que o Brasil possui comitê nacional do ICOM desde o ano de $1948,{ }^{123}$ e, segundo

institucional

119 BRASIL. Lei ñ 11.904, de 14 de janeiro de 2009. Institui o Estatuto de Museus e dá outras providências. Disponível em: http://www. planalto.gov.br/ccivil_03/_ato2007-2010/2009/lei/111904.htm Acesso em: 23 jul. 2019.

120 BRASIL. Lei no 11.904, de 14 de janeiro de 2009. Institui o Estatuto de Museus e dá outras providências. Disponível em: http://www. planalto.gov.br/ccivil_03/_ato2007-2010/2009/lei/111904.htm Acesso em: 23 jul. 2019.

121 BRASIL. Lei no 11.904, de 14 de janeiro de 2009. Institui o Estatuto de Museus e dá outras providências. Disponível em: http://www. planalto.gov.br/ccivil_03/_ato2007-2010/2009/lei/111904.htm Acesso em: 23 jul. 2019.

122 BRASIL. Decreto n ${ }^{\circ} 8.124$, de 17 de outubro de 2013. Regulamenta Dispositivos da Lei $\mathrm{n}^{\circ}$ 11.904, de 14 de janeiro de 2009, que institui o Estatuto de Museus, e da Lei no 11.906, de 20 de janeiro de 2009, que cria o Instituto Brasileiro de Museus-IBRAM. Disponível em: http://www.planalto.gov.br/ccivil_03/_ato2011-2014/2013/decreto/d8124.htm Acesso em: 23 jul. 2019.

${ }^{123}$ COMITÊ BRASILEIRO DO CONSELHO INTERNACIONAL DE MUSEUS. O ICOM Brasil. Disponível em: https://www. as regras institucionais do ICOM e o Estatuto Social do Comitê Brasileiro, ${ }^{124}$ os membros — pessoas físicas ou instituições - estão obrigados a seguirem suas normas internas. Contudo, apenas a menção do nome da instituição não é uma fonte segura de que seus preceitos, como o Código de Ética, estão, de fato, sendo relevantes como guia na formação de decisão pública e, no caso, na decisão do legislador brasileiro.

Visando a uma maior compreensão e difusão do texto, o Código de Ética do ICOM foi traduzido para o português de maneira conjunta pelo Comitê Brasileiro e o Comitê Português, sendo uma exigência do ICOM que uma tradução passe a ser considerada oficial apenas após a aprovação de, pelo menos, um comitê nacional que possua o idioma como nativo. O resultado final do texto data de 2008. ${ }^{125}$ A estrutura base do Código de Ética ICOM é composta por preâmbulo; oito títulos, cada um vinculado a um princípio geral, seguido de respectivos subtópicos com relação temática e glossário.

Para uma melhor e mais embasada conclusão do eventual — impacto do Código de Ética do ICOM para elaboração das normas gerais brasileiras para museus, é oportuno usar como base os títulos 1 (um) e 7 (sete) do Código de Ética, e sua definição de "museu", comparando com o conteúdo do Estatuto de Museus (Lei n. ${ }^{\circ}$ 11.904/2009), da Lei de Criação do Instituto Brasileiro de Museus - IBRAM (Lei n. ${ }^{\circ} 11.906 / 2009$ ) e com o Decreto n. ${ }^{\circ} 8.124 / 2013$, que regulamenta as leis anteriores.

\subsection{Missão, instalações e estrutura física dos museus}

O título e princípio 1 (um) do Código de Ética do ICOM sintetizam um sentido de "missão" dos museus e aspectos essenciais de estrutura física e de pessoal para que o museu possa existir adequadamente. Diz o título 1: "Os museus preservam, interpretam e promovem o

icom.org.br/?page_id=12. Acesso em: 5 jun. 2021.

${ }^{124}$ COMITE BRASILEIRO DO CONSELHO INTERNACIONAL DE MUSEUS. Estatuto Social do Comitê Brasileiro do Conselho Internacional de Museus. Disponível em: http://www.icom.org.br/wpcontent/uploads/2013/05/Estatuto-ICOM-BR.pdf Acesso em: 5 jun. 2021.

125 COMITE BRASILEIRO DO CONSELHO INTERNACIONAL DE MUSEUS. Versão Lusófona do Código de Ética para Museus ICOM. Disponível em: http://icom.org.br/wpcontent/themes/ colorwaytheme/pdfs/codigo $\% 20 \mathrm{de} \% 20$ etica/codigo_de_etica_lusofono_iii_2009.pdf Acesso em: 6 jun. 2021. 
patrimônio natural e cultural da humanidade". O princípio 1, por sua vez, é:

\begin{abstract}
Os museus são responsáveis pelo patrimônio natural e cultural, material e imaterial. As autoridades de tutela e todos os responsáveis pela orientação estratégica e a supervisão dos museus têm como primeira obrigação proteger e promover este patrimônio, assim como prover os recursos humanos, materiais e financeiros necessários para este fim.
\end{abstract}

Nesse título estão estabelecidos os parâmetros para ações éticas sobre os seguintes temas: a) Constituição Institucional: 1.1. Documentos constitutivos; ${ }^{126}$ 1.2. Definição legal de missões, objetivos e políticas institucionais; ${ }^{127}$ b) Recursos Materiais: 1.3. Instalações; 1.4. Acesso 1.5. Saúde e Segurança; 1.6. Proteção contra sinistros; 1.7. Condições de segurança; 1.8. Seguro e indenização; c) Recursos Financeiros: 1.9. Financiamento; 1.10. Política para geração de receitas; d) Recursos Humanos: 1.11. Política de emprego; 1.12 Nomeação de diretor ou responsável; 1.13. Acesso às autoridades de tutela; 1.14. Competências do pessoal de museu; 1.15. Formação de pessoal; 1.16. Conflito ético; 1.17. Profissionais de museu e voluntários; 1.18 Voluntários e ética.

A definição de "museu" no glossário do Código de Ética ICOM é esta:

Os museus são instituições permanentes, sem fins lucrativos, ao serviço da sociedade e do seu desenvolvimento, abertas ao público, que adquirem, preservam, pesquisam, comunicam e expõem, para fins de estudo, educação e lazer, os testemunhos materiais e imateriais dos povos e seus ambientes.

Na lei brasileira, por sua vez, o conceito de "museu" está expresso no Estatuto de Museus $\left(\operatorname{artigo} 1^{\circ}\right.$ ) e, no Decreto n. ${ }^{\circ} 8.124 / 2013$ (artigo $2^{\circ}$, IX), nos seguintes termos:

\footnotetext{
Instituição sem fins lucrativos, de natureza cultural, que conserva, investiga, comunica, interpreta e expõe, para fins de preservação, estudo, pesquisa, educação, contemplação e turismo, conjuntos e coleções de valor histórico, artístico, científico, técnico ou de outra natureza cultural, abertos ao público, a serviço da sociedade e de seu desenvolvimento.
}

\footnotetext{
126 Definição no Código de Ética: "a autoridade de tutela tem a responsabilidade de assegurar que o museu tenha um estatuto, um regimento ou outro documento oficial, conforme a legislação nacional em vigor, estipulando claramente o estatuto jurídico do museu, sua missão, sua permanência e seu caráter não lucrativo."

127 Definição no Código de Ética: "a autoridade de tutela deve elaborar, tornar público e cumprir um texto legal que defina a missão, os objetivos e as políticas do museu, assim como seu próprio papel e composição".
}

Depreende-se desses textos muita semelhança, sendo possível destacar pequenas mudanças nas palavras utilizadas, mas que carregam mesmo sentido em conjunto. O "lazer", no conceito do ICOM, não consta na definição brasileira, mas a lei nacional usou as palavras "contemplação" e "turismo". Elas podem se relacionar com a finalidade dos museus em proporcionar "lazer" aos seus visitantes. Por outro, o termo "turismo" pode ser interpretado como uma evidência da atribuição de relevância econômica indireta aos equipamentos culturais, para o legislador brasileiro.

Quanto à "Constituição Institucional", referida no Código de Ética ICOM, a lei brasileira trouxe a obrigação de formalização legal dos estabelecimentos museológicos, na forma tanto do Regimento Interno ${ }^{128}$ quanto do "Plano Museológico". No Estatuto de Museus (artigos 44, 45, 46 e 47), e de maneira mais completa no Decreto n. ${ }^{\circ}$ 8.124/2013 (artigo 23), o Plano Museológico é um dever do museu que, preferencialmente, deve elaborar este documento "de forma participativa, envolvendo o conjunto dos funcionários dos museus, além de especialistas, parceiros sociais, usuários e consultores externos, levadas em conta suas especificidades." 129 O Plano Museológico é uma ferramenta básica tanto de planejamento estratégico da atuação do museu, como para o diagnóstico de público, identificação das instalações, definição sobre expedientes internos, prioridades e seu papel e missão perante a sociedade que está inserido.

O Decreto n. ${ }^{\circ} 8.124 / 2013$, no artigo 23 , inciso IV e alíneas, indica o conteúdo mínimo de programas que o Plano Museológico deve versar: a) institucional; b) de gestão de pessoas; c) de acervos; d) de exposições; e) educativo e cultural; f) de pesquisa; g) arquitetônico-urbanístico; h) de segurança; i) de financiamento e fomento; j) de comunicação; k) socioambiental.

Quanto às exigências de "recursos materiais" mínimos para o funcionamento do museu, especialmente

\footnotetext{
128 BRASIL. Decreto $n^{\circ}$ 8.124, de 17 de outubro de 2013. Regulamenta Dispositivos da Lei $\mathrm{n}^{\circ} 11.904$, de 14 de janeiro de 2009, que institui o Estatuto de Museus, e da Lei no 11.906, de 20 de janeiro de 2009, que cria o Instituto Brasileiro de Museus-IBRAM. Disponível em: http://www.planalto.gov.br/ccivil_03/_ato2011-2014/2013/decreto/d8124.htm Acesso em: 23 jul. 2019.

129 BRASIL. Decreto n ${ }^{\circ} 8.124$, de 17 de outubro de 2013. Regulamenta Dispositivos da Lei $\mathrm{n}^{\circ}$ 11.904, de 14 de janeiro de 2009, que institui o Estatuto de Museus, e da Lei no 11.906, de 20 de janeiro de 2009, que cria o Instituto Brasileiro de Museus-IBRAM. Disponível em: http://www.planalto.gov.br/ccivil_03/_ato2011-2014/2013/decreto/d8124.htm Acesso em: 23 jul. 2019.
} 
sobre as instalações, o Estatuto de Museus determina que os museus deverão dispor de instalações adequadas ao cumprimento das funções necessárias e ao bem-estar dos usuários e funcionários. ${ }^{130}$ Sobre o acesso, saúde segurança e condições de segurança do acervo, o Decreto n. ${ }^{\circ}$ 8.124/2013 dispõe que a garantia da acessibilidade universal é uma competência dos museus. ${ }^{131}$ Ou seja, é uma competência o IBRAM a elaboração, divulgação e manutenção de material atualizado com recomendações técnicas relacionadas a acessibilidade. ${ }^{132}$ Segundo o Plano Museológico, no programa arquitetônico, é necessário ser assegurada acessibilidade física e linguagem expográfica voltadas às pessoas com deficiência. ${ }^{133}$ O plano de segurança no Plano Museológico trata de aspectos relacionados à segurança, edificação, acervo e públicos interno e externo, incluídos sistemas, equipamentos e instalações, bem como a definição de rotinas de segurança e estratégias de emergência. ${ }^{134}$

No Estatuto de Museus, há o cuidado de mencionar que o acesso aos bens culturais nos museus devem ser regulamentados pela respectiva instituição levando em conta a segurança e conservação do acervo. ${ }^{135}$ Há uma subseção intitulada "Da Preservação, da Conservação, da Restauração e da Segurança” na qual, em relação aos artigos 23 ao 27, existem obrigações sobre prevenção de perigos contra a integridade do acervo, instalações e funcionários, sendo um dever dos museus manter condições indispensáveis de segurança, e regras de segurança interna tem caráter confidencial. ${ }^{136}$ Apenas quanto ao ponto específico de seguro e indenização, não há obrigação legal expressa na lei brasileira para a cobertura de seguro dos itens do acervo, se a segurança local for realizada por empresa privada.

Quanto ao procedimento ético no financiamento das atividades do museu e na captação de recursos, tanto no Estatuto de Museus quanto no Decreto n. ${ }^{\circ}$ $8.124 / 2013$, há a previsão de que o financiamento e o fomento devem estar especificados no Plano Museo-

\footnotetext{
130 BRASIL. Decreto n 8.124, de 17 de outubro de 2013. Regulamenta Dispositivos da Lei $\mathrm{n}^{\circ} 11.904$, de 14 de janeiro de 2009, que institui o Estatuto de Museus, e da Lei n ${ }^{\circ} 11.906$, de 20 de janeiro de 2009, que cria o Instituto Brasileiro de Museus-IBRAM. Disponível em: http://www.planalto.gov.br/ccivil_03/_ato2011-2014/2013/decreto/d8124.htm Acesso em: 23 jul. 2019.

131 Artigo $4^{\circ}$.

132 Artigo $3^{\circ}$, inciso $\mathrm{V}$, alínea $\mathrm{f}$.

133 Artigo 23, inciso IV, alínea g.

134 Artigo 23, inciso IV, alínea h.

135 Artigo 31, parágrafo único.

136 Artigo 23, parágrafo único; Artigo 27.
}

lógico; e o Decreto especifica que eles se referem às estratégias de captação, aplicação e gerenciamento dos recursos econômicos. ${ }^{137}$ Finalmente, no artigo 21, foi criado o Programa de Fomento aos Museus e à Memória Brasileira, vinculado ao Plano Setorial de Museus. $\mathrm{Na}$ lei de criação do IBRAM (Lei n. ${ }^{\circ}$ 11.906/2009), já havia sido atribuída a este instituto a competência de desenvolver e apoiar programas de financiamento para o setor museológico.

\subsection{Recursos humanos para museus}

Na sequência do Título 1, há disposições sobre "Recursos Humanos". O subitem 1.11. intitulado "Política de emprego" tem a seguinte descrição: "a autoridade de tutela deve assegurar que todas as medidas relativas a recursos humanos sejam tomadas de acordo com as políticas do museu e com a legislação em vigor.” Adiante, há a recomendação de nomeação de diretor ou responsável do museu por qualificação intelectual, conhecimentos profissionais e ética compatíveis com a função (1.12). Ademais, os diretores dos museus devem prestar contas e ter acesso direto às autoridades ou instituições mantenedoras (1.13); deve ser admitido pessoal qualificado para atender todas as responsabilidades dos museus (1.14); e deve ser feita oferta de formação continuada e desenvolvimento profissional para todo o pessoal do museu, para aperfeiçoamento da gestão (1.15).

Nesse sentido encontram-se, nas leis brasileiras, disposições compatíveis com o rigor técnico no exercício profissional exigido pelo Código de Ética ICOM. O Decreto n. ${ }^{\circ} 8.124 / 2013$, artigo 34, afirma que os dirigentes dos museus administrados pelo IBRAM (museus federais) serão selecionados segundo critérios técnicos e objetivos, baseados na formação, conhecimento do setor de museus e políticas públicas da área, bem como será relevante a experiência em gestão — elementos estes verificados por meio de um processo de seleção pública. No Estatuto de Museus, aplicável aos museus públicos e àqueles que escolherem fazer parte do Sistema Brasileiro de Museus, há obrigação de manter funcionários devidamente qualificados, bem como de garantir a quantidade suficiente de funcionários para atender às necessidades da atividade. ${ }^{138} \mathrm{~A}$ legislação estabelece que

\footnotetext{
37 Artigo 23, inciso IV, alínea i.

138 Artigo 17 caput e parágrafo único.
} 
o IBRAM, por sua vez, deve fomentar a permanente qualificação e a valorização dos recursos humanos. ${ }^{139}$

Por fim, as políticas oficiais e padrões éticos se aplicam também aos voluntários, se o museu admitir esse tipo de colaboração. Aliás, espera-se haver bom relacionamento entre voluntários e profissionais de museu (itens 1.17 e 1.18). A lei brasileira abriu a possibilidade de criação de associação de amigos de museus e programas de voluntariado, desde que isso gere benefício mútuo. ${ }^{140}$ As associações de amigos devem ter por finalidade o apoio e colaboração com os museus, contribuindo para seu desenvolvimento e para a preservação do patrimônio museológico. ${ }^{141}$

\subsection{Quadro jurídico internacional aplicável}

Seguindo a análise comparativa entre a lei brasileira e o Código de Ética do ICOM, pode ser tomado como parâmetro também o item 7 , por se tratar da parte pertinente ao Quadro Jurídico. Os museus, para terem uma condução ética, segundo as normas do ICOM, precisam respeitar toda a legislação em vigor, seja do Direito interno ou externo. O princípio 7 do Código de Ética tem a seguinte redação:

\footnotetext{
Os museus devem funcionar de acordo com a legislação internacional, regional, nacional ou local em vigor e com compromissos decorrentes de tratados. Além disso, a autoridade de tutela deve cumprir todas as obrigações legais ou outras condições relativas aos diferentes aspectos que regem o museu, seus acervos e seu funcionamento.
}

No subitem 7.2, estão elencadas as convenções internacionais que a política de museus deve reconhecer,

\footnotetext{
139 BRASIL. Lei $n^{\circ}$ 11.906, de 20 de janeiro de 2009. Cria o Instituto Brasileiro de Museus - IBRAM, cria 425 (quatrocentos e vinte e cinco) cargos efetivos do Plano Especial de Cargos da Cultura [...]. Disponível em: http://www.planalto.gov.br/ccivil_03/_ato20072010/2009/lei/111906.htm Acesso em: 23 jul. 2019.

140 BRASIL. Decreto $n^{\circ} 8.124$, de 17 de outubro de 2013. Regulamenta Dispositivos da Lei $\mathrm{n}^{\circ}$ 11.904, de 14 de janeiro de 2009, que institui o Estatuto de Museus, e da Lei no 11.906, de 20 de janeiro de 2009, que cria o Instituto Brasileiro de Museus-IBRAM. Disponível em: http://www.planalto.gov.br/ccivil_03/_ato2011-2014/2013/decreto/d8124.htm Acesso em: 23 jul. 2019.

141 BRASIL. Decreto n $n^{\circ} 8.124$, de 17 de outubro de 2013. Regulamenta Dispositivos da Lei $\mathrm{n}^{\circ} 11.904$, de 14 de janeiro de 2009, que institui o Estatuto de Museus, e da Lei n 11.906 , de 20 de janeiro de 2009, que cria o Instituto Brasileiro de Museus-IBRAM. Disponível em: http://www.planalto.gov.br/ccivil_03/_ato2011-2014/2013/decreto/d8124.htm Acesso em: 23 jul. 2019.
}

e que são usadas como referência à interpretação do Código de Ética.

Das sete convenções citadas, o Brasil ratificou seis: UNESCO - Convenção para a Proteção de Bens Culturais em caso de Conflito Armado (Convenção de Haia, Primeiro Protocolo, de 1954, e segundo Protocolo, de 1999):; $;^{142}$ UNESCO - Convenção sobre a Forma de Proibir e Prevenir a Importação, Exportação e Transferência Ilícitas de Bens Culturais (1970):;43 Convenção sobre o Comércio Internacional de Espécies da Fauna e Flora Silvestres em Extinção (1973); ${ }^{144}$ UN - Convenção sobre a Diversidade Biológica (1992): ${ }^{145}$ Unidroit - Convenção sobre Bens Culturais Roubados e Ilegalmente Exportados (1995):; ${ }^{146}$ UNESCO - Convenção sobre a Salvaguarda do Patrimônio Cultural Imaterial (2003). ${ }^{147}$ A convenção que o Brasil não ratificou e não assinou foi a Convenção UNESCO sobre a Proteção do Patrimônio Cultural Submarino (2001). ${ }^{148}$

\section{Considerações finais}

Não existe, formalmente, uma obrigação legal de o Estado brasileiro, seja por meio do Executivo ou do Legislativo, seguir normas regulamentadoras criadas por instituições como o International Council of Museum (ICOM). Contudo, o reconhecimento de doutrinas jurídicas como a do soft law, bem como o consolidado regime de proteção internacional do patrimônio cultural, ${ }^{149}$ ao longo do século XX, foram redesenhando os contornos sobre as fontes do Direito, soberania ${ }^{150}$ e a des-

142 Decreto n. $^{\circ} 5.760$, de 24 de abril de 2006, DOU 25/04/06.

143 Decreto 72.312, de 31 de maio de 1973, DOU 08/06/73.

144 Decreto n. ${ }^{\circ}$ 76.623, de 17 de novembro de 1975, DOU 19/11/75; Implementação pelo Decreto n. ${ }^{\circ} 3.607 / 2000$.

145 Decreto n. ${ }^{\circ}$ 2.519, de 16 de março de 1998, DOU 17/03/98; Regulamentada pela Lei n. ${ }^{\circ} 13.123 / 2015$.

146 Decreto n. ${ }^{\circ} 3.166$, de 14 de setembro de 1999, DOU 15/09/99.

147 Decreto n. $^{\circ}$ 5.753, de 12 de abril de 2006, DOU 13/04/06.

148 UNESCO. Non-Ratified Conventions - Brazil. Disponível em: http://www.unesco.org/eri/la/conventions_by_country.asp?contr $=\mathrm{BR} \&$ language $=\mathrm{E} \&$ typeconv $=0$ Acesso em: 2 jun. 2020 .

149 GALERA, Susana Galera. The benefits of legal globalization. Soft law: a case study of heritage law. The Historic Environment: Policy \& Practice, v. 7, n. 2-3, p. 237-247, abr. 2016.

${ }_{150}$ Cenário de globalização da economia internacional já vem intensificando este processo e trazendo desafios aos Estados, redesenhando os contornos da soberania nacional com a formação de blocos econômicos e progressiva integração global. FRANCA FILHO, Marcílio Toscano. Westphalia: a paradigm? a dialog between law, art and philosophy of science. Revista da ESMAFE, Recife, v. 13, p. 117- 
centralização de focos de poder que outrora eram tidos como incontestes. Instituições como o ICOM carregam uma autoridade simbólica e podem passar a ser uma importante fonte normativa para os gestores do setor e, também, para o aperfeiçoamento legislativo e democrático dessas políticas.

Roubos de peças de arte e destruição de monumentos por nazistas durante a Segunda Guerra Mundial fizeram emergir preocupações especiais sobre a preservação de bens culturais, cuja reação da comunidade internacional deu origem à primeira convenção internacional sobre o tema, a Convenção de Haia de 1954 sobre Proteção de Propriedade Cultural em Caso de Conflito Armado. ${ }^{151}$ A Convenção UNESCO para Proteção do Patrimônio Mundial, Cultural e Natural, de 1972, ${ }^{152}$ deu origem à expressão "outstanding universal value" para classificar bens culturais, nas formas de monumentos, conjuntos, lugares notáveis e patrimônio cultural que seriam relevantes para a humanidade, independente da origem destes vestígios de importância reconhecida.

Embora essas convenções não digam respeito, especificamente, à prática museológica, e sejam documentos de natureza jurídica distinta das normas do ICOM, elas ilustram um princípio que justifica uma rede de proteção global dos bens culturais da qual o ICOM também faz parte: o atentado e a privação de acesso de uma manifestação cultural em um lugar no mundo afeta, na verdade, todo o globo. Obras de arte, fósseis, documentos, invenções, artefatos de povos originários, roupas de outros tempos ou quaisquer itens que contém a história da civilização humana, da fauna e flora, ou expressem o gênio criativo do ser humano, dizem respeito a toda a humanidade em alguma medida. Partindo desse pressuposto, a importância da existência de um Código de Ética como do ICOM e o reconhecimento de sua força normativa toma contornos mais evidentes.

Uma vez existindo base mínima comum para o manejo desses tipos de bens culturais fica assegurada uma prática museológica (menos) refém de quaisquer intem-

202, mar. 2017. p. 201-202.

151 SIEHR, Kurt. Legal aspects of the mystification and demystification of cultural property. Art Antiquity \& Law, v. 16, n. 3, p. 173-214, out. 2011. p. 179. Disponível em: https:// heinonline.org/HOL/LandingPage?handle=hein.journals / artniqul16\&div $=22 \&$ id $=$ \&page $=$ Acesso em: 15 jul. 2020 .

152 GALERA, Susana Galera. The benefits of legal globalization. Soft law: a case study of heritage law. The Historic Environment: Policy \& Practice, v. 7, n. 2-3, p. 237-247, abr. 2016. p. 239. péries políticas em âmbito nacional, seja por falta de expertise técnica ou por falta de recursos financeiros e humanos; seja, ainda, pela ausência de vontade política interna para a elaboração de políticas e lei responsivas e adequadas para um setor tão complexo e sensível. A flexibilidade de uma norma de soft law, como é o Código de Ética do ICOM, se torna uma vantagem, pois qualquer profissional do setor, de qualquer lugar do mundo, pode se basear nele, independentemente da ratificação por parte do Estado, sobretudo nos casos em que não haveria vontade política para fazer parte de algum tratado internacional sobre o tema. Ainda que representante do Estado tenha assinado a convenção, em situações de forte instabilidade na política interna, casas legislativas muito fragmentadas podem apresentar entraves para a ratificação de Direito internacional de temas como arte e cultura, que podem sofrer resistência por motivos ideológicos.

Outra vantagem é o fortalecimento de um sistema jurídico já positivado, compatibilizando o rigor técnico reconhecido mundialmente com ferramentas institucionais e legais que facilitarão — teoricamente — a aplicação dessas normas no dia a dia, gerando obrigações legais e direitos pleiteáveis no Judiciário.

Essa base internacional, pautada em práticas rediscutidas por um corpo de profissionais em relações inter-organizacionais e intergovernamentais, fruto de constantes trocas, revisões e deliberações, com transparência e procedimentos previamente estabelecidos, trazem mais confiança no teor das normas do ICOM e produzem legitimidade. Os conflitos éticos na prática museológica ocorrerão, e o que o Código de Ética apresenta não são soluções simples ou respostas prontas, tampouco se confunde com alguma espécie de moralidade subjetiva. Na realidade, são oferecidos princípios objetivos para guiar as ações com um senso de dever para o interesse público (bem comum).${ }^{153} \mathrm{O}$ museu deve cumprir seu papel de interpretar o patrimônio natural e cultural comprometido com o desfazimento de injustiças históricas. ${ }^{154}$

Independentemente do cenário, é muito positivo que haja uma norma internacional como o Código de Ética do ICOM visando à padronização das práticas

153 MURPHY, Bernice L. Charting the ethics landscape for museums in a changing world. In: MURPHY, Bernice L. (ed.). Museums, ethics and cultural heritage. Londres; Nova York: Routledge, 2016. p. 32. 154 Parte do "Princípio 1" do Código de Ética ICOM. 
museológicas, pois isso permite um sistema ideal que reconhece que todo o bem cultural seja tratado com o mesmo zelo, independentemente de sua origem. Esta pode ser, em última análise, uma espécie de imperativo categórico que justifica a existência de um Código de Ética mundialmente aceito no setor museológico, fomentando responsabilidade e integridade nas ações internas dos países.

O Brasil possui uma vasta produção normativa sobre museus, proteção, fomento e difusão de bens culturais. As normas gerais para o setor museológico são muito detalhadas e, analisando, de maneira sistemática e pormenorizada, em alguns tópicos sensíveis, é possível afirmar que o Brasil está, no quadro jurídico, em consonância com o Código de Ética do ICOM e convenções internacionais do sistema de proteção de patrimônio cultural. E o respeito a esse conjunto normativo de soft law é algo positivo para o sistema de proteção, sendo compatível com os objetivos da Constituição de 1988 e seu modelo de Estado Social.

O planejamento e diretrizes jurídicas no setor de museus, na organização institucional, segue a tendência consolidada pelo ICOM de uma gestão em rede, que soa muito destoante da estrutura tradicional de poder no Estado concebido numa estrutura clássica de hierarquia. ${ }^{155}$ Os mecanismos de fomento na política cultural e o sistema em rede dos museus, que engloba instituições tanto públicas, quanto privadas (ou da sociedade civil), demonstram que o papel Estado centralizador/ unilateral, como tradicionalmente concebido, não é uma constante no setor museológico. Atualmente, o sistema jurídico exige que ele atue como agregador e coordenador. As normas do ICOM que fortemente inspiraram a lei brasileira demonstram um claro protagonismo de novos atores não públicos nos processos de decisão e como fonte normativa. Enquanto o Sistema Brasileiro de Museus é uma rede doméstica, o ICOM atua, globalmente, como uma "rede de redes". 156

\footnotetext{
155 Sobre o paradigma pós-estadualista ou pluralista, ver: GUSSOLI, Felipe Klein. Hierarquia supraconstitucional relativa dos tratados internacionais de direitos humanos. Revista de Investigações Constitucionais, Curitiba, v. 6, n. 3, p. 703-747, set./dez. 2019.

156 No original: "acts globally as a 'network of networks"'. MURPHY, Bernice L. Charting the ethics landscape for museums in a changing world. In: MURPHY, Bernice L. (ed.). Museums, ethics and cultural heritage. Londres; Nova York: Routledge, 2016. p. 23. Tradução livre.
}

Esse cenário atual de imbricação entre o Direito internacional e o Direito administrativo demonstra uma via de mão dupla, uma retroalimentação jurídica. Resta evidenciada a influência direta das normas de atores não estatais no Direito interno, como o ICOM e seu Código de Ética, ou de organismos internacionais intergovenamentais como a UNESCO, mas a regulamentação do Direito interno dos bens e patrimônio culturais, por reconhecer estes bens de interesse público, também incentivam a criação de normas internacionais. ${ }^{157}$ Afinal, quanto mais se reforça a relevância pública desses bens, mais merecedores de proteção e regulação eles se tornam, inclusive em nível global. Desse modo, parece altamente positiva tal influência recíproca.

O Brasil, além de ter leis setoriais compatíveis com o Código de Ética, teve sua atuação administrativa destacada no Report on the implementation of the UNESCO 2015 Recommendation on Museums \& Collections, de 2019. ${ }^{158}$ Para avaliar a situação legislativa e arranjos institucionais para museus dos países-membros da UNESCO, após a Resolução de 2015 sobre museus e coleções, foram enviados questionários, dando origem ao primeiro mapeamento sobre o tema em nível global promovido pela UNESCO. As respostas foram recebidas em dezembro de 2018.

No tópico "2. Administrative framework for the organization of the museum sector", em relação aos cinquenta e seis países que responderam, apenas o Brasil e outros quatro países declararam que tinham entidades autônomas para gerenciar os museus no país. ${ }^{159}$ Os demais responderam que a responsabilidade era de departamentos dentro de Ministério do Executivo, seja específico para museus ou integrado com patrimônio cultural ou antiguidades. O IBRAM foi citado no relatório como uma agência com papel muito ativo na coordenação e coleta de informações do setor no Brasil. No tópico "3. Specific legislative means and tools to respond to the frameworl referred to em the Recommendation", as perguntas se referiam a polí-

\footnotetext{
${ }^{157}$ CASINI, Lorenzo. "Italian Hours": the globalization of cultural property law. International Journal of Constitutional Law, v. 9, n. 2, p. 369-393, abr. 2011. p. 392-393.

158 UNESCO. Report on the implementation of the UNESCO 2015 Recommendation on Museums \& Collections. Paris, 2019. Disponível em: http://inclusivemuseums.org/wp-content/ uploads/2019/11/781371549eng.pdf Acesso: 14 jul. 2020.

159 Iran, Maurício, Suécia e Zimbábue. UNESCO. Report on the implementation of the UNESCO 2015 Recommendation on Museums \& Collections. Paris, 2019. Disponível em: http://inclusivemuseums.org/ wp-content/uploads/2019/11/781371549eng.pdf Acesso: 14 jul. 2020. p. 29.
} 
ticas para salvaguardar as main function dos museus, que seriam para os fins da recomendação: preservação; pesquisa; educação e comunicação. O Brasil ficou no grupo dos dez membros com o maior número declarado de instrumentos normativos e ações em favor daqueles elementos supracitados, para implementar a Resolução UNESCO de 2015. Foi destacado o protagonismo do Brasil nas ações postas em prática para o cumprimento do papel social do museu, especialmente na diversidade cultural e acessibilidade. As atividades do IBRAM se tornaram de competência reconhecidas no campo da museologia social, conclui o Relatório. ${ }^{160}$

Por fim, com base nos textos legais que fizeram parte do recorte deste trabalho, destaca-se, apenas, um ponto que pode gerar eventual dissonância com o Código de Ética do ICOM: a inclusão de "turismo" como uma das finalidades dos museus no Brasil no conceito de "museu" na lei brasileira. Museus são importantes centros de troca cultural, e muitos atraem visitação não só pelas exposições, mas pelo prédio que o abriga, tornando-se um ponto turístico com claras vantagens econômicas locais - e este, a princípio, não é um fator negativo, apesar das controvérsias no entorno da questão.

Reforça essa ideia a existência de uma íntima relação entre museus e projetos arquitetônicos de referência como, por exemplo, no Museu do Amanhã no Rio de Janeiro-Brasil, projetado pelo famoso arquiteto espanhol Santiago Calatrava, e o Museu Oscar Niemeyer em Curitiba-Brasil, projetado pelo famoso arquiteto brasileiro que dá nome à edificação. Isoladamente, o turismo não é um problema, mas é necessário ter redobrado cuidado para que aos museus não seja destinado o lugar do abandono em razão de uma abordagem meramente utilitarista e mercantilizada - afinal, nem todos têm vocação para a complementar exploração econômica.

Ao se fazer uma associação simplista entre custo-benefício na criação e manutenção de um museu, a sua função social e relevância cultural são prejudicadas. A situação se agrava em cenários como o do Brasil, a partir de 2019, em que a gestão do governo federal passou a realizar reformas das pastas ministeriais em prejuízo do sistema, fundadas na ênfase mercadológica e no re-

\footnotetext{
${ }^{160}$ UNESCO. Report on the implementation of the UNESCO 2015 Recommendation on Museums \& Collections. Paris, 2019. Disponível em: http://inclusivemuseums.org/wp-content/ uploads/2019/11/781371549eng.pdf Acesso: 14 jul. 2020. p. 31-32, 46.
}

torno da clássica e anacrônica ideia de uma "hegemônica identidade nacional" — há muito abandonada internacionalmente ${ }^{161}$ e que remete à prática brasileira da primeira metade do século XX.

O Instituto Brasileiro de Museus (IBRAM), juntamente a várias outras instituições culturais nacionais, como a Fundação Biblioteca Nacional (FBN) e Agência Nacional de Cinema (ANCINE), passaram a ser vinculadas ao Ministério do Turismo. Todavia, a criação de museus com o intuito de movimentação turística não pode ser a vocação prioritária da área. Várias são as externalidades negativas que podem ser geradas, além de problemas éticos (como a falta de planejamento para manutenção adequada dos museus) e burocráticos (como utilização de pessoal não qualificado). Nesse processo de promoção de turismo cultural, frequentemente ocorrem desvios da ética por conveniência - a rápida expansão do número de museus na Ásia, em especial na China e Taiwan, é um exemplo negativo nesta seara. ${ }^{162}$

Em conclusão, depois de um período de forte aprimoramento do regime jurídico e do sistema entre o final da década de 1980 e meados da segunda década do século XXI, são evidentes os retrocessos atuais no ambiente museológico brasileiro. Será necessário um forte engajamento da sociedade civil e de instituições públicas e privadas para sustentar o modelo até então conquistado e que, apesar de insuficiente, já foi um importante passo à frente na proteção da cultura e da história dos brasileiros.

\section{Referências}

ALMEIDA, Eneida de. O "construir no construido" na produção contemporânea: relações entre teoria e prática. 2009. Tese (Doutorado em Arquitetura e Urbanismo) - Universidade de São Paulo, São Paulo, 2009.

ALVARADO, Arturo. The Brazilian Constitution of 1988: a comparative appraisal. Revista de Investigações Constitucionais, Curitiba, v. 5, n. 3, p. 137-148, set./dez. 2018.

161 As teses identitárias de Ernesto Araújo, Ministro do Governo de Jair Bolsonaro, ilustram a política pública anacrônica e cientificamente ultrapassada que foi implementada pelo Poder Executivo brasileiro. ARAÚJO, Ernesto Henrique Fraga Araújo. Trump e o Ocidente. Cadernos de Politica Exterior, v. 3, n. 6, dez. 2017.

162 EDSON, Gary. Unchanging ethics in a changing world. In: MURPHY, Bernice L. (ed.). Museums, ethics and cultural heritage. Londres; Nova York: Routledge, 2016. p. 133. 
ANDRADE JUNIOR, Nivaldo Vieira de. Ampliações do conceito de patrimônio edificado no Brasil. In: GOMES, Marco Aurélio A. de Filgueiras; Elyane Lins Corrêa (orgs.). Reconceituações contemporâneas do patrimônio. Salvador: EDUFBA, 2011.

ARAÚjO, Ernesto Henrique Fraga Araújo. Trump e o Ocidente. Cadernos de Política Exterior, v. 3, n. 6, dez. 2017.

BESSA, Simone Figueiredo. Musealização e ordenamento jurídico do Museu no Brasil: missão e função (conceito e prática) no Museu Nacional - UFRJ (séculos XIX-XX). 2017. Dissertação (Mestrado em Museologia e Patrimônio) - Universidade Federal do Estado do Rio de Janeiro, Rio de Janeiro, 2017.

BRASIL, Deilton Ribeiro; GOMES, Elaine Aparecida Barbosa. A diversidade cultural enquanto direito fundamental: o caso do povo indígena Wayãpi. Revista Direito Econômico e Socioambiental, v. 10, n. 3, p. 258-287, set./ dez. 2019.

BRASIL. Câmara dos Deputados. A tramitação dos atos internacionais no Congresso Nacional. Disponível em: https:/ / www2.camara.leg.br/atividade-legislativa/estudos-enotas-tecnicas/publicacoes-da-consultoria-legislativa/ copy_of_portas-abertas-1/Palestra9.pdf Acesso em: 13 jul. 2020.

BRASIL. Decreto n 10.108, de 7 de novembro de 2019.

Anexo ao Decreto $n^{\circ} 9.660$, de $1^{\circ}$ de janeiro de 2019, que dispõe sobre a vinculação das entidades da administração pública federal indireta. Disponível em: http:/ / www.planalto.gov.br/ccivil_03/_ato2019-2022/2019/ decreto/D10108.htm Acesso em: 23 jul. 2019.

BRASIL. Decreto $n^{\circ} 5.264$, de 5 de novembro de 2004. Institui o Sistema Brasileiro de Museus e dá outras providências. Disponível em: http://www.planalto.gov.br/ ccivil_03/_ato2004-2006/2004/decreto/d5264.htm Acesso em: 23 jul. 2019.

BRASIL. Decreto no 8.124, de 17 de outubro de 2013. Regulamenta Dispositivos da Lei $\mathrm{n}^{\circ} 11.904$, de 14 de janeiro de 2009, que institui o Estatuto de Museus, e da Lei ${ }^{\circ}$ 11.906, de 20 de janeiro de 2009, que cria o Instituto Brasileiro de Museus-IBRAM. Disponível em: http:// www.planalto.gov.br/ccivil_03/_ato2011-2014/2013/ decreto/d8124.htm Acesso em: 23 jul. 2019.

BRASIL. Decreto-Lei $n^{\circ} 25$, de 30 de novembro de 1937. Organização e proteção do Patrimônio Histórico e Artísti- co Nacional. Disponível em: http://www.planalto.gov. br/ccivil_03/decreto-lei/del0025.htm Acesso em: 23 jul. 2019.

BRASIL. Lei $n^{0} 11.904$, de 14 de janeiro de 2009. Institui o Estatuto de Museus e dá outras providências. Disponível em: http://www.planalto.gov.br/ccivil_03/_ ato2007-2010/2009/lei/111904.htm Acesso em: 23 jul. 2019.

BRASIL. Lei no 11.906, de 20 de janeiro de 2009. Cria o Instituto Brasileiro de Museus - IBRAM, cria 425 (quatrocentos e vinte e cinco) cargos efetivos do Plano Especial de Cargos da Cultura [...]. Disponível em: http:/ / www.planalto.gov.br/ccivil_03/_ato2007-2010/2009/ lei/111906.htm Acesso em: 23 jul. 2019.

BRASIL. Lei ñ 12.343, de 2 de dezembro de 2010. Institui o Plano Nacional de Cultura - PNC, cria o Sistema Nacional de Informações e Indicadores Culturais e dá outras providências. Disponível em: http://www.planalto. gov.br/ccivil_03/_ato2007-2010/2010/lei/112343.htm Acesso em: 23 jul. 2019.

BRASIL. Ministério da Cidadania. Secretaria Especial da Cultura. Sistema Nacional de Cultura. Disponível em: http:// cultura.gov.br/sistema-nacional-de-cultura/ Acesso em: 23 jul. 2019.

BRASIL. Ministério da Cultura. Diretrizes Gerais para o Plano Nacional de Cultura. 2. ed. Brasília: Ministério da Cultura, 2008.

BREPOHL, Marion; GONÇALVES, Marcos; GABARDO, Emerson. As violências do estado de exceção e a defesa da memória contra a invisibilidade dos grupos vulneráveis. Revista Brasileira de Estudos Políticos, Belo Horizonte, n. 117, p. 321-361, jul./dez. 2018.

BRUS, Marcel M. J. A. Soft law in public internacional: a pragmatic or a principle choice? comparing the sustainable development goals and the Paris Agreement. In: WESTERMAN, Pauline et al. (eds.). Legal validity and soft law. Nova York: Springer, 2018. p. 243-266.

CANCLINI, Néstor García. Culturas híbridas: estratégias para entrar e sair da modernidade. 2. ed. São Paulo: Edusp, 1998.

CAPONIGRI, Felicia. The ethics of the international display of fashion in the museum. Case Western Reserve Journal of International Law, Cleveland, v. 49, n. 1, 2017.

CARVALHO, Osvaldo Ferreira de. As políticas públicas como concretização dos direitos sociais. Revista de 
Investigações Constitucionais, Curitiba, v. 6, n. 3, p. 773-794, set./dez. 2019.

CASINI, Lorenzo. "Italian Hours": the globalization of cultural property law. International Journal of Constitutional Law, v. 9, n. 2, p. 369-393, abr. 2011.

COMITÊ BRASILEIRO DO CONSELHO INTERNACIONAL DE MUSEUS. Estatuto Social do Comitê Brasileiro do Conselho Internacional de Museus. Disponível em: $\quad$ http://www.icom.org.br/wp-content/uploads/2013/05/Estatuto-ICOM-BR.pdf Acesso em: 5 jun. 2021.

COMITE BRASILEIRO DO CONSELHO INTERNACIONAL DE MUSEUS. Home. Disponível em: http://www.icom.org.br/ Acesso: 5 de jun. 2021.

COMITE BRASILEIRO DO CONSELHO INTERNACIONAL DE MUSEUS. Versão Lusófona do Código de Ética para Museus ICOM. Disponível em: http:// icom.org.br/wpcontent/themes / colorwaytheme/ pdfs/codigo $\% 20 \mathrm{de} \% 20$ etica/codigo_de_etica_lusofono_iii_2009.pdf Acesso em: 6 jun. 2021.

\section{CONSEIL INTERNACIONAL DES MONUMENTS}

ET DES SITES. Historique. Disponível em: https:// www.icomos.org/fr/a-propos-de-licomos/mission-etvision/historique. Acesso em: 2 jul. 2021.

CUNHA FILHO, Francisco Humberto; SALDANHA, Bianca de Souza. A desapropriação como instituto de proteção ao patrimônio cultural e análise da legislação aplicável. A\& C - Revista de Direito Administrativo \& Constitucional, Belo Horizonte, ano 18, n. 71, p. 197-224, jan./mar. 2018.

CUNHA, Fernando José Gonçalves; ARAFA, Mohamed A.; BENVINDO, Juliano Zaiden. The Brazilian Constitution of 1988 and its ancient ghosts: comparison, history, and the ever-present need to fight authoritarianism. Revista de Investigações Constitucionais, Curitiba, v. 5, n. 3, p. 17-41, set./dez. 2018.

EDSON, Gary. Unchanging ethics in a changing world. In: MURPHY, Bernice L. (ed.). Museums, ethics and cultural heritage. Londres; Nova York: Routledge, 2016.

ELLIS, Jaye. Shades of grey: soft law and the validity of public international law. Leiden Journal of International Law, Cambridge, v. 25, n. 2, p. 313-334, 2012.

FONSECA, Maria Cecília Londres. Patrimônio em processo: trajetória da política federal de preservação no Brasil. Rio de Janeiro: UERJ, 1997.
FRANCA FILHO, Marcílio Toscano. As diretivas da Comunidade Européia: elementos para uma teoria geral. Revista de Direito Constitucional e Internacional, ano 9, n. 37, p. 7-26, out./dez. 2001.

FRANCA FILHO, Marcílio Toscano. Westphalia: a paradigm? a dialog between law, art and philosophy of science. Revista da ESMAFE, Recife, v. 13, p. 117-202, mar. 2017.

FRANCA FILHO, Marcílio Toscano; VALE, Matheus C. do; SILVA, Nathálya L. da. Mercado de arte, integridade e due diligence no Brasil e no Mercosul cultural. Revista de la Secretaría del Tribunal Permanente de Revisión, ano 7, n. 14, p. 260-282, ago. 2019.

FREITAS, Vladimir Passos de; FREITAS, Gilberto Passos de. Reflexões sobre a proteção penal do patrimônio histórico e cultural brasileiro. Revista de Direito Econômico e Socioambiental, Curitiba, v. 6, n. 1, p. 88-113, jan./jun. 2015.

FRIGO, Manlio. Ethical rules and codes of honor related to museum activities: a complementary support to the private international law approach concerning the circulation of cultural propert. International Journal of Cultural Property, v. 16, n. 1, p. 49-66, fev. 2009.

GABARDO, Emerson. O princípio da supremacia do interesse público sobre o interesse privado como fundamento do direito administrativo social. Revista de Investigaçoes Constitucionais, Curitiba, v. 4, n. 2, p. 95-130, maio/ago. 2017.

GABARDO, Emerson; REZENDE, Maurício Corrêa de M. O conceito de interesse público no direito administrativo brasileiro. Revista Brasileira de Estudos Políticos, Belo Horizonte, n. 115, p. 267-318, jul./dez. 2017.

GABARDO, Emerson; SALGADO, Eneida Desiree. El sistema de protección del patrimonio histórico urbano y minero en Brasil. Revista Catalana de Dret Ambiental, v. 9, n. 1, p. 1-26, 2018.

GALERA, Susana Galera. The benefits of legal globalization. Soft law: a case study of heritage law. The Historic Environment: Policy \& Practice, v. 7, n. 2-3, p. 237-247, abr. 2016.

GARLANDINI, Alberto. ICOM's museum definition, code of ethics, and policy in favour of museums and heritage. In: SYMPOSIUM ICOFOM Defining the Museum of the 21st century, 2017, St Andrews: defining museums 
of the 21st century: plural experiences. Paris: ICOM/ ICOFOM, 2018.

GOMES, Enéias Xavier. Direito fundamental à tutela do patrimônio cultural. Fórum de Direito Urbano e Ambiental-FDUA, Belo Horizonte, ano 14, n. 81, p. 16-21, maio/jun. 2015.

GUSSOLI, Felipe Klein. Hierarquia supraconstitucional relativa dos tratados internacionais de direitos humanos. Revista de Investigações Constitucionais, Curitiba, v. 6, n. 3, p. 703-747, set./dez. 2019.

HACHEM, Daniel Wunder. A dupla noção jurídica de interesse público em direito administrativo. $A \& C-R e-$ vista de Direito Administrativo \& Constitucional, Belo Horizonte, ano 11, n. 44, p. 59-110, abr./jun. 2011.

HACHEM, Daniel Wunder. São os direitos sociais “direitos públicos subjetivos"? Mitos e confusões na teoria dos direitos fundamentais. Revista de Estudos Constitucionais, Hermenêutica e Teoria do Direito, v. 11, n. 3, p. 404-436, set./dez. 2019.

HERSCHER, Ellen. The antiquities market: news and commentary on the illicit traffic on antiquities. Journal of Field Archaeology, v. 14, n. 2, p. 213-223, jun./set. 1987.

INSTITUTO BRASILEIRO DE MUSEUS. Museus em números. 2011. Disponível em: http://www.museus.gov. br/wp-content/uploads/2011/11/museus_em_numeros_volume1.pdf Acesso em: 23 jul. 2019.

INSTITUTO BRASILEIRO DE MUSEUS. Resolucão Normativa $n^{\circ}$ 2, de 29 de maio de 2019. Regulamenta a Declaração de Interesse Público de bens culturais musealizados ou passíveis de musealização. Disponível em: https://www.in.gov.br/web/dou/-/resolucao-normativa-n-2-de-29-de-maio-de-2019-157603410 Acesso em: 23 jul. 2019.

INSTITUTO DO PATRIMÔNIO HISTÓRICO E ARTÍSTICO NACIONAL. Bens tombados e processos em andamento. Maio, 2019. Disponível em: http://portal. iphan.gov.br/uploads/ckfinder/arquivos/BENS $\% 20$ TOMBADOS $\% 20 \mathrm{E} \% 20 \mathrm{PROCESSOS} \% 20 \mathrm{EM} \% 20$ ANDAMENTO\%202019\%20MAIO.pdf Acesso em: 12 jul. 2019.

INSTITUTO DO PATRIMÔNIO HISTÓRICO E ARTÍSTICO NACIONAL. Carta de Atenas (1931). Disponível em: http://portal.iphan.gov.br/uploads/ ckfinder/arquivos/Carta\%20de\%20Atenas\%201931. pdf Acesso em: 2 de jul. 2020.
INSTITUTO DO PATRIMÔNIO HISTÓRICO E ARTÍSTICO NACIONAL. Carta de Veneza (1964). Disponível em: http://portal.iphan.gov.br/uploads/ ckfinder/arquivos/Carta\%20de\%20Veneza \%201964. pdf Acesso em: 2 jul. 2020.

INTERNATIONAL COMMITTEE FOR MUSEOLOGY. Home. Disponível em: http://icofom.mini. icom.museum/ Acesso em: 25 jun. 2021.

INTERNATIONAL COUNCIL OF MUSEUM. Home. Disponível em: https://icom.museum/en/ Acesso em: 25 jun. 2021.

INTERNATIONAL COUNCIL OF MUSEUMS. Statutes as amended and adopted by the Extraordinary General Assembly on 9th June 2017 (Paris, France). Disponível em: https://icom.museum/wp-content/uploads/2018/07/2017_ICOM_Statutes_EN.pdf Acesso em: 5 jul. 2021.

JUBILUT, Liliana Lyra. Os fundamentos do direito internacional contemporâneo: da coexistência aos valores compartilhados. Anuário Brasileiro de Direito Internacional, Belo Horizonte, v. 2, n. 9, p. 203-219, 2010.

KINGSBURY, Benedict. The concept of 'law' in global administrative law. European Journal of International Law, Oxford, v. 20, n. 1, p. 23-57, fev. 2009.

KRISCH, Nico; KINGSBURY, Benedict. Introdução: governança global e direito administrativo global na ordem legal internacional. $\mathrm{RDA}$ - Revista de Direito Administrativo, Rio de Janeiro, v. 261, p. 13-32, set. 2012.

LEAL, Mônia Clarissa Hennig; MORAES, Maria Valetina de. "Diálogo" entre poderes no Brasil?: da inconstitucionalidade da regulação da vaquejada à vaquejada como patrimônio cultural imaterial brasileiro: uma análise crítica. Revista de Investigações Constitucionais, Curitiba, v. 5, n. 1, p. 63-81, jan./abr. 2018.

LIMA, Diana Farjalla Correia. Museologia-Museu e patrimônio, patrimonialização e musealização: ambiência de comunhão. Boletim do Musen Paraense Emílio Goeldi Ciências Humanas, Belém, v. 7, n. 1, p. 31-50, jan./abr. 2012.

LOPES, Rodrigo T. Dias; GOMES, Larissa Rizzatti. Políticas públicas e museus no Estado de São Paulo: dos museus histórico-pedagógicos ao sistema estadual de museus. Educação, Batatais, v. 7, p. 49-63, jul./dez. 2017.

MELO, Douglas Brandão de; CARVALHO, Rita de Cássia Moura. Relações entre patrimônio cultural e 
museus: um referencial teórico para o desenvolvimento. Mosaico, v. 7, n. 10, 2016. Disponível em: http://bibliotecadigital.fgv.br/ojs/index.php/mosaico/article/ view/ 64725 Acesso em: 12 mar. 2019.

MURPHY, Bernice L. Charting the ethics landscape for museums in a changing world. In: MURPHY, Bernice L. (ed.). Museums, ethics and cultural heritage. Londres; Nova York: Routledge, 2016.

NOHARA, Irene Patrícia. Direito administrativo. 9. ed. São Paulo: Atlas, 2019.

OLIVEIRA, Thiago Pires. Raízes históricas da proteção jurídica do patrimônio cultural no Brasil. Fórum de Direito Urbano e Ambiental - FDUA, Belo Horizonte, ano 11, n. 62, mar./abr. 2012.

ORGANIZAÇÃO DAS NAÇÕES UNIDAS. Statute of The International Court of Justice - ICJ. São Francisco, 26 de junho de 1945. Disponível em: https://www.icj-cij. org/en/statute Acesso em: 13 jul. 2020.

POZZER, Márcio Rogério Olivato. Os paradigmas da administração pública e as políticas de patrimônio cultural em museus de Brasil e México. São Paulo, 2015. Tese (Doutorado em Comunicação) - Escola de Comunicação e Artes, Universidade de São Paulo, São Paulo, 2015.

POZZER, Marcio Rogerio Olivato. Políticas públicas para o patrimônio cultural na América Latina: a experiência brasileira e equatoriana e o papel do Banco Interamericano de Desenvolvimento. 2011. Dissertação (Mestrado em Integração da América Latina) - Integração da América Latina, Universidade de São Paulo, São Paulo, 2011.

REYNA, Justo José. El procedimiento administrativo multidimensional como técnica regulatoria en materia ambiental, de patrimonio cultural y de pueblos originarios. A\&C-Revista de Direito Administrativo \& Constitucional, Belo Horizonte, ano 12, n. 50, p. 131-169, out./ dez. 2012.

ROBILANT, Anna di. Genealogies of Soft Law. The American Journal of Comparative Law, v. 54, n. 3, p. 499554, jul. 2006. Disponível em: https:/ /www.researchgate.net/publication/256003377_Genealogies_of_Soft_ Law Acesso em: 20 jun. 2020.

SANTOS, Myrian Sepúlveda dos. Museu imperial: a construção do Império pela República. In: CHAGAS, Mário; ABREU, Regina (orgs.). Memória e patrimônio: ensaios contemporâneos. 2. ed. Rio de Janeiro: Lamparina, 2009.
SANTOS, Myrian Sepúlveda dos. Museus brasileiros e política cultural. Revista Brasileira de Ciências Sociais, São Paulo, v. 19, n. 55, p. 53-72, jun. 2004. Disponível em: http://www.scielo.br/scielo. php?script $=$ sci_arttext\&pid=S01026909200400020000 4\&lng=en\&nrm=iso Acesso em: 25 jul. 2019.

SIEHR, Kurt. Legal aspects of the mystification and demystification of cultural property. Art Antiquity \& Law, v. 16, n. 3, p. 173-214, out. 2011. Disponível em: https:/ / heinonline.org/HOL/LandingPage?handle=hein. journals $/$ artniqul1 $6 \&$ div $=22 \&$ id $=\&$ page $=$ Acesso em: 15 jul. 2020.

SILVA, Alice R. da; SANTOS, Ruth Maria. P dos. As diretivas europeias como norma reguladora do direito administrativo global. Brazilian Journal of International Law, Brasília, v. 13, n. 3, 2016.

SILVA, Carlos Henrique Gomes da; PINHEIRO, Lena Vania Ribeiro. Políticas públicas para museus no Brasil: do IPHAN ao IBRAM. In: ENCONTRO NACIONAL DE PESQUISA EM CIÊNCIA DA INFORMAÇÃO, 14., 2013, Florianópolis. Anais [...]. Florianópolis: UFSC, 2013. Disponível em: http://repositorio.ibict. br/handle/123456789/459 Acesso em: 12 mar. 2019.

SNYDER, Francis. The Effectiveness of European Community Law: Institutions, Processes, Tools and Techniques. The Modern Law Review, v. 56, n. 1, p. 19-54, jan. 1993.

SOUZA, Leonardo da Rocha de; LEISTER, Margareth Anne. A influência da soft law na formação do direito ambiental. Brazilian Journal of International Law, Brasília, v. 12, n. 2, 2015.

TALLER, Adriana. Los instrumentos de gestión urbana promotores de los derechos económicos, sociales culturales y ambientales. Revista Eurolatinoamericana de Derecho Administrativo, Santa Fé, v. 5, n. 1, p. 5-28, jan./ jun. 2018.

TALLER, Adriana. Derecho a la preservación del patrimonio arquitectónico urbano: un desafío para las autoridades locales. Revista Eurolatinoamericana de Derecho Administrativo, Santa Fé, v. 1, n. 2, p. 7-37, jul./dez. 2014.

TEUBNER, Gunther. Breaking frames: economic globalisation and the emergence of lex mercatoria. European Journal of Social Theory, v. 5, p. 199-217, 2002.

TEUBNER, Gunther. Global bukowina: legal pluralism in the world-society. In: TEUBNER, Gunther (ed.). 
Global law without a state. Dartmouth: Aldershot, 1997. p. 3-28.

THOMPSON, Hilary H. International law, and its vision of the ideal museum. Curator: The Museum Journal, v. 51, n. 1 , p. 5-10, jan. 2008.

TOLENTINO, Átila Bezerra. Políticas públicas para museus: o suporte legal no ordenamento jurídico brasileiro. Revista CPC, São Paulo, n. 4, p. 72-86, maio/out. 2007.

UNESCO. Non-Ratified Conventions - Brazil. Disponível em: http://www.unesco.org/eri/la/conventions_by_ country.asp? contr $=B R \&$ language $=\mathrm{E} \&$ typeconv $=0$ Acesso em: 2 jun. 2020.

UNESCO. Recommendation concerning the Protection and Promotion of Museums and Collections, their Diversity, and their Role. 2015. Disponível em: http://www.unesco.org/ new/en/culture/themes/museums/recommendationon-the-protection-and-promotion-ofmuseums-andcollections/ Acesso: 14 jul. 2020.

UNESCO. Report on the implementation of the UNESCO 2015 Recommendation on Museums \& Collections. Paris, 2019. Disponível em: http://inclusivemuseums.org/ wp-content/uploads/2019/11/781371549eng.pdf Acesso: 14 jul. 2020.

UNESCO. Shenzhen Declaration on Museums and Collections. High Level Forum on Museums, Shenzhen, 10 de 12 November 2016. Disponível em: http://www.unesco. org/new/fileadmin/MULTIMEDIA/HQ/CLT/pdf/ Shenzhen_Declaration-en.pdf Acesso em: 14 jul. 2020.

UNIÃO EUROPEIA. European Commission. Disponível em: https://europa.eu/european-union/about-eu/ institutions-bodies/european-commission_en Acesso em: 11 jul. 2020.

VAN DER SLUIJS, Jessika. Soft law: an international concept in a national context. Scandinavian Studies in Law, v. 58, p. 285-306, dez. 2013. 
Para publicar na Revista de Direito Internacional, acesse o endereço eletrônico www.rdi.uniceub.br ou www.brazilianjournal.org.

Observe as normas de publicação, para facilitar e agilizar o trabalho de edição. 